\title{
Social-Environmental Analysis for the Management of Coastal Lagoons in North Africa
}

\author{
Badr El Mahrad ${ }^{1,2,3 *}$, Samuel Abalansa ${ }^{3}$, Alice Newton ${ }^{3,4}$, John D. Icely ${ }^{3}$, Maria Snoussi ${ }^{5}$ \\ and llias Kacimi ${ }^{2}$
}

'Murray Foundation, Brabners LLP, Liverpool, United Kingdom, ${ }^{2}$ Laboratory of Geoscience, Water and Environment (LG2E-CERNE2D), Department of Earth Sciences, Faculty of Sciences, Mohammed V University of Rabat, Rabat, Morocco, ${ }^{3}$ CIMA, FCT-Gambelas Campus, University of Algarve, Faro, Portugal, ${ }^{4}$ NILU-IMPACT, Kjeller, Norway, ${ }^{5}$ Department of Earth Sciences, Faculty of Sciences, Mohammed V University of Rabat, Rabat, Morocco

OPEN ACCESS

Edited by:

J. Guy Castley,

Griffith University, Australia

Reviewed by:

Lorena Rodríguez-Gallego,

Universidad de la República, Uruguay

Andreea Nita,

University of Bucharest, Romania

${ }^{*}$ Correspondence:

Badr El Mahrad

badr.elmahrad@gmail.com

Specialty section:

This article was submitted to

Conservation,

a section of the journal

Frontiers in Environmental Science

Received: 26 September 2019

Accepted: 17 March 2020

Published: 23 April 2020

Citation:

El Mahrad B, Abalansa S,

Newton A, Icely JD, Snoussi $M$ and Kacimi I (2020) Social-Environmental Analysis for the Management of Coastal Lagoons in North Africa.

Front. Environ. Sci. 8:37.

doi: 10.3389/fenvs.2020.00037
This study provides an overview of 11 lagoons in North Africa, from the Atlantic to the Eastern Mediterranean. Lagoons are complex, transitional, coastal zones providing valuable ecosystem services that contribute to the welfare of the human population. The main economic sectors in the lagoons included fishing, shellfish harvesting, and salt and sand extraction, as well as maritime transport. Economic sectors in the areas around the lagoons and in the watershed included agriculture, tourism, recreation, industrial, and urban development. Changes were also identified in land use from reclamation, changes in hydrology, changes in sedimentology from damming, inlet modifications, and coastal engineering. The human activities in and around the lagoons exert multiple pressures on these ecosystems and result in changes in the environment, affecting salinity, dissolved oxygen, and erosion; changes in the ecology, such as loss of biodiversity; and changes in the delivery of valuable ecosystem services. Loss of ecosystem services such as coastal protection and seafood affect human populations that live around the lagoons and depend on them for their livelihood. Adaptive management frameworks for social-ecological systems provide options that support decision makers with sciencebased knowledge to deliver sustainable development for ecosystems. The framework used to support the decision makers for environmental management of these 11 lagoons is Drivers-Activities-Pressures-State Change-Impact (on Welfare)-Responses (as Measures).

Keywords: coastal lagoons, North Africa, water management, environmental assessment, adaptive management frameworks, social-ecological systems, DAPSI(W)R(M) a modified DPSIR, ecosystem services

\section{HIGHLIGHTS}

- A social-environmental analysis of 11 North African coastal lagoons.

- The behavior of users is similar across North African lagoons.

- Responses (as measures) to problems are identified.

- Adaptive management of coastal lagoons can deliver more ecosystem services.

\section{INTRODUCTION}

Coastal lagoons are important zones for life between the land and the sea. They are one of the most productive environments and deliver ecosystem services (ES) that provide many ecological, 
cultural, and socioeconomic benefits, supporting a range of natural services that are highly valued by society (Gönenç and Wolflin, 2005; Newton et al., 2018). In the specific case of North Africa, coastal lagoons have a wide geographical distribution extending from the Atlantic Ocean along the western coastline of Morocco to the southern coastline of the Mediterranean Sea through Morocco, Algeria, Tunisia, Libya, and Egypt. In common with other regions of the world (Newton et al., 2014), the terminology used for North African lagoons varies from country to country and even among different regions in the same country that use different dialects and languages. These differences in terminology complicate research into historical knowledge about these lagoons systems. Nonetheless, it has been possible to identify most of the terms needed for this study (see section "Discussion").

Areas surrounding lagoons in North Africa have a long history of human occupation and utilization (Ramdani et al., 2001; Thompson and Flower, 2009; Trigui et al., 2012). These important social-ecological systems (SESs) continue to be heavily impacted by human activities, such as extraction of freshwater and urbanization, as well as the development of economic sectors, for example, fisheries, agriculture and tourism. Many of these SES are provided with some legal protection through international conventions, particularly for the protection of bird communities, in the case of Ramsar sites (Ramdani et al., 2009a; Sayoud et al., 2017). However, current levels of exploitation are unsustainable, and there is an increasing need for an integrated, basin-wide approach to the management of water resources and aquatic ecosystems in the region (Thompson and Flower, 2009). Indeed, there have been recent research projects to improve the understanding of these lagoon ecosystems and their surrounding resources (see section Supplementary Material).

The variety of issues in North African coastal lagoons (ecological functioning, biodiversity, productivity, human uses) requires conceptual models to organize, understand, and clarify issues and recapitulate information in a standard, logical, and hierarchical method (Patrício et al., 2016). The DAPSI(W)R(M) [Drivers-Activities-Pressures-State ChangesImpacts (on Welfare)-Responses (as Measures)] framework (Elliott et al., 2017) is the conceptual model that has been followed for the social environmental analysis of coastal lagoons in North Africa. In the context of this study, State refers to environmental state (e.g., water quality), ecological state (e.g., biodiversity), and consequently state of ES. This analysis enables local planners and state regulators to identify management solutions and measures for adaptation to changes in the lagoon ecosystems. An important aspect of these measures is the maintenance and improvement in the ES that these lagoons provide for human welfare.

\section{MATERIALS AND METHODS}

\section{Study Sites: Distribution of North African Lagoons}

North Africa is defined as the Southern Mediterranean Region or the North of the African Sahara (Desert). It is an area surrounded by the Atlantic Ocean to the west of Morocco, by the Mediterranean Sea to the north of Morocco, as well as the coast of Algeria, Tunisia, Libya, and Egypt, and by the Red Sea to the east of Egypt (Figure 1).

There are 22 lagoons in North Africa, 4 along the Atlantic shore of Morocco and 18 along the South Mediterranean Region. They are shallow systems, permanently linked to the sea and regulated by tidal exchanges and fluxes at the sediment interface.

Eleven lagoon sites were selected on the basis of available data and literature; the importance of their social ecological and economic roles in the chosen countries; and their different key environmental characteristics in terms of basin surface, land use distribution, typology, lagoon size, the adjacent sea (Atlantic, Mediterranean), dynamics, and climate. The 11 coastal lagoons include Khenifiss and Oualidia (Morocco) along the Atlantic shore, and Nador (Morocco), El Mellah (Algeria), Bizerte (Tunisia), Tunis (Tunisia) and Boughrara (Tunisia), Farwa (Libya), Marsa Matrouh (Egypt), Bardawil (Egypt), and Burullus (Egypt) along the Mediterranean shore (names in white on black background, Figure 1).

\section{Data Sources and Collection}

The data were found in web-based searches using Web of Knowledge (ISI Web of Science), Science Direct (Scopus), Google Scholar, and Google searches. Searches were constrained to the period from 2000 to 2018 to focus on the most recent publications (531 articles). This identified peer-reviewed articles in ISI journals (e.g., 89 for Nador), as well as a significant body of "gray" literature (106 reports), such as reports by Environmental agencies or Ministries (e.g., 15 for Nador). There was considerable variation in the number of sources available for the different systems (e.g., 104 for Nador, only 24 for Kenifiss).

The search words were applied in English, French, and Arabic. Most of the articles listed in the References are from peer-reviewed literature in English and French, published for an international audience. There is also a substantial literature in Arabic and French, which is used in the North African countries for reports, which was consulted for this review, but this is not listed in the References.

The search keywords that were used, both singly and in combination, were as follows: "name" of the lagoon, including local variations on their names, see section "Confusion About Nomenclature of Lagoons in the Context of North African Lagoons"; "lagoon, lake, lac, lagune"; "country," also in the different languages." The studies identified were selected in a systematic manner based on title and abstract eligibility according to keywords, and then the full texts were screened. Many studies were removed because of missing data (313 articles and reports).

We then extracted information about the lagoons in relation to the drivers, activities, pressures, state changes, impacts, humans, and welfare issues as identified by Elliott et al. (2017) (e.g., agriculture, $\mathrm{pH}$ change, and underwater noise). The reported presence and absence of various activities/pressures/state changes/impact (on welfare) in the studied lagoons were extracted and tabulated, with some quantitative and qualitative details mentioned in each result section, if data were available (e.g., number of catches, number of boats, input of pollutants). 


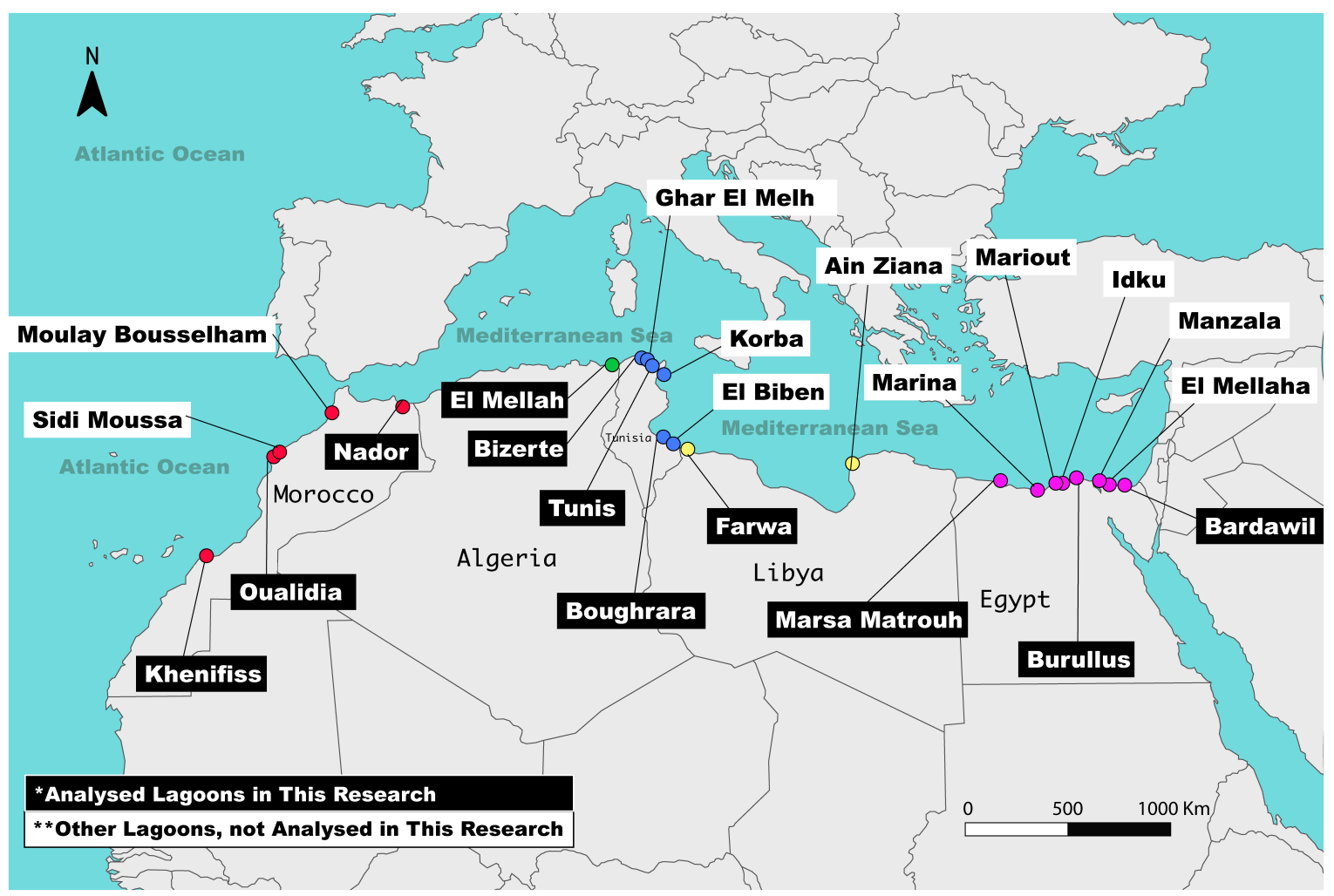

FIGURE 1 | Location of North African lagoons. The lagoon names in white on a black background* were analyzed in detail; those in black on white ${ }^{\star \star}$ were not analyzed. The dots show the lagoons in Morocco (red), Algeria (green), Tunisia (blue), Libya (yellow), and Egypt (purple).

\section{Analytical Framework}

DAPSI(W)R(M), a social-ecological framework for adaptive management from Elliott et al. (2017), was used for the analysis of the lagoons. This framework has evolved from earlier versions (Gari et al., 2015) starting with the PSR (Pressures-StateResponse) framework proposed by Rapport and Friend (1979) and then developed and supported by the Organization for Economic Cooperation and Development (OECD) to organize its work on environmental policies and reporting (OECD, 1994). A later version is the DPSIR [Drivers-Pressures-State-Impacts (on Welfare)-Responses (as Measures)] used by, among others, the US Environmental Protection Agency (EPA, 1994), the United Nations Environment Programme (UNEP, 1994), the European Environment Agency (EEA, 1995), and the European Commission (EU, 2000). Patrício et al. (2016) and Elliott et al. (2017) highlight the anomalies and focus on the confusions of each component of DPSIR as a reason for improving the framework; for practicable management purposes, they advocate an extension of the framework to DAPSI $(W) R(M)$. In this version, Drivers or driving forces indicate the basic needs of humans (Maslow, 1943), such as food, transport, and goods. These needs are addressed by society through socioeconomic Activities, such as fishing, aquaculture, and building infrastructure that have effects that produce Pressures, such as overextraction of resources, input of nutrients and/or heavy metals, $\mathrm{pH}$ changes, and so on. These effects lead to State changes on the ecology of the environment, as well as on the intermediate and final ES (Elliott et al., 2017). These changes have Activities (on human Welfare), such as provisioning services (e.g., fish food), regulating services (e.g., healthy climate), and cultural services (e.g., tourism). Responses (as Measures) to changes resulting from drivers, activities, and pressures require scientific knowledge to produce appropriate laws for governance, as well as a range of economic mechanisms and technologies to implement the appropriate management (Wolanski and Elliott, 2015; Elliott et al., 2017).

\section{RESULTS}

\section{Drivers of Changes in North African Lagoons}

Societal Drivers in relation to North African lagoon context are outlined below:

Stage 1_basic biological and physiological needs: these are fundamental necessities for all humans such as food, drink, shelter, and so on.

Stage 2_safety needs: these include protection from inclement natural phenomena, such as storms, droughts, and floods; law and order; allowing for the use of goods and services from lagoons; political stability; and allowing North African populations to live without fear. 
Stage 3_love and belonging needs: these represent interpersonal relationships among North Africans; friendship, trust, and acceptance; receiving and giving affection and even love. At the scale of an individual, this involves belonging to a group, having friends, and creating a family. It also includes the behavior of stakeholders (e.g., fishers, farmers, workers), citizenship, and being part of society.

Stage 4_esteem needs: these are represented by an individual's achievements, self-respect, and status that are part of the common culture among North African people. For instance, men (e.g., fishers) are still the main wage earners of the household with their work providing them self-respect and the respect of others in the context of the local culture.

Stage 5_self-actualisation: the final stage is represented by realizing personal fulfillment. For example, the decision makers responsible for the Nador lagoon are trying to provide economic growth for the region based on sustainable management of the goods and services. By ensuring successful management of this type of ecosystem, they are setting an excellent case study not only for North Africa but also for the other countries in Africa and elsewhere.

\section{Activities Associated With North African Lagoons}

The assessment based on the human activities associated with North African lagoons is related mainly to general activities associated with major sectors rather than individual, specific activities. Table $\mathbf{1}$ summarizes some of the more important activities (adapted from Smith et al., 2016) occurring in these lagoons that are presented in more detail in the following sections.

As far as possible, a common style and content has been used for the description of these activities, but there are big differences in the content and quantity of data that are available for the different lagoons.

\section{Extraction of Living Resources and Aquaculture Fishing}

Artisanal fisheries have been identified as common activity in all lagoons, which has increased in the last decades due to growth in local demand linked to urban growth. The fisheries activities use small fishing boats because the lagoons are shallow waters (only a few meters). The boats are called "feluccas" in Morocco, Algeria, and Tunisia or "marceb" in Libya and Egypt.

Khenifiss lagoon (Morocco), an ecosystem protected from UNESCO World Heritage, has few fishing and aquaculture activities at present. Fisheries are more developed in Nador lagoon, where the tonnage of the fish catches increased from 480 tons in 2001 to 1,157 tons in 2012, which represents an increase of $241 \%$. The monthly net profit per boat is approximately 222 Euros (2,465 Moroccan Dirhams). Overall, the main fish catches are eel (i.e., Anguilla anguilla), bream (i.e., Sparus aurata), and gray and red mullet (i.e., Mullus barbatus). Other catches include cuttlefish, octopus (i.e., Octopus vulgaris), and shrimp (i.e., Penaeus japonicus). The 887 fishers of this lagoon are all male with an average age of 41 years (including sailors), while boat owners are of an average age of 48 years. For $46 \%$ of fishers, fishing is their only economic activity, whereas the others work seasonally in agriculture or small commerce (Najih et al., 2015).

The Mellah lagoon (Algeria) is also well known for its artisanal fishery activities with an annual average fish production of approximately 40 tons. The production comprises eels (58\%), followed by mullet (31\%) represented by Mugil cephalus, Liza aurata, Liza saliens, Liza ramada, and Chelon labrosus. There is also harvesting of mollusks including clams (i.e., Ruditapes decussatus) and cockles (i.e., Cerastoderma glaucum) (Chaoui et al., 2006). The only available data about fishers are from 1982, with 13 fishers supervised by the Enterprise Nationale Algérienne de Pêche-Unité Aquacole; they are all male with an average age of 44 years, supporting a total of 67 children (Food and Agriculture Organization, 1982).

The catch from Farwa lagoon (Libya) is 26 tons annually, mainly fish, shellfish, and octopus, but there are no available data about numbers of fishers (Banana and Mohamed, 2016).

Fishing production in Egypt has increased from an annual production of 140,400 tons in 1980 to $1,079,500$ tons in 2009, with 934,000 tons coming from inland areas. This is an important sector for the country, representing 2 billion Euros in income. Egyptian lagoons represent $27.8 \%$ of total fisheries production in the country and are mostly for crab (El Nahas et al., 2017).

The reason for the large variation in the number of fishers and catches among North African lagoons depends on the size of the lagoon (both area and depth), as well as the population surrounding the lagoon.

\section{Aquaculture}

Moroccan aquaculture started in the 1950s with the launch of shellfish farming in the Oualidia lagoon, with a pilot project for breeding oysters. Currently, a dozen farms continue to operate at this lagoon. Oyster production reached 60 tons in 2011, with shell fishing representing $15 \%$ of total production in the region (Maanan et al., 2014).

Shellfish production in Tunisia started in 1964 in Bizerte lagoon (Ghribi et al., 2016) and included mussels, oysters, and clams (Fertouna-Bellakhal et al., 2014; Turki et al., 2014). Current production is more than 100 tons per year.

In Libya, mussel and oyster cultivation is ongoing at aquaculture farms on Farwa lagoon.

In Egypt, fish farms have been developed along the lagoon shores of Burullus. The annual production is approximately 52,000 tons (Eid and Shaltout, 2014). Bardawil lagoon (Egypt) is a rich environment for the extraction of living resources. The production of high-quality fish is mainly exported to Europe, enabling an increase in economic development (El-Kassas et al., 2016). This activity produces approximately $80 \%$ of the exported fish and crustacea from Egyptian lagoons (El-Kassas et al., 2016; Nassar et al., 2018).

\section{Agriculture and Golf}

Agricultural practices have a high impact on lagoons environments. In North Africa, many lagoons are surrounded by agriculture and, in some cases, have been modified by land reclamation, draining, and infilling to enable agriculture (e.g., Burullus in Egypt). In recent years, some areas around lagoons 
TABLE 1 | The major economic sectors and activities in North African lagoons: "X" represents documented, and "?" undocumented" activities.

\begin{tabular}{|c|c|c|c|c|c|c|c|c|c|c|c|}
\hline \multirow{2}{*}{$\begin{array}{l}\text { Country } \\
\text { Lagoon }\end{array}$} & \multicolumn{3}{|c|}{ Morocco } & \multirow{2}{*}{$\frac{\text { Algeria }}{\text { El Mellah }}$} & \multicolumn{3}{|c|}{ Tunisia } & \multirow{2}{*}{$\begin{array}{c}\text { Libya } \\
\text { Farwa }\end{array}$} & \multicolumn{3}{|c|}{ Egypt } \\
\hline & Khenifiss & Oualidia & Nador & & Bizerte & Tunis & Boughrara & & Marsa Matrouh & Burullus & Bardawil \\
\hline \multicolumn{12}{|c|}{ Activity/economic sector } \\
\hline $\begin{array}{l}\text { Extraction of living } \\
\text { resources }\end{array}$ & $x$ & $x$ & $x$ & $x$ & $x$ & $x$ & $x$ & $x$ & $x$ & $x$ & $x$ \\
\hline Aquaculture & $x$ & $x$ & $x$ & $x$ & $x$ & $x$ & $x$ & $x$ & $x$ & $x$ & \\
\hline Agriculture & & $x$ & $x$ & $x$ & $x$ & & & $?$ & $x$ & $x$ & $x$ \\
\hline Golf & & & $x$ & & & & & & $x$ & & \\
\hline Tourism and recreation & & $x$ & $x$ & $?$ & & $x$ & & $x$ & $x$ & $x$ & $x$ \\
\hline $\begin{array}{l}\text { Extraction of non-living } \\
\text { resources }\end{array}$ & & $x$ & $x$ & & & & & $x$ & $x$ & & $x$ \\
\hline Land-based industry & & $X$ & $x$ & $x$ & $x$ & $x$ & $x$ & $x$ & $X$ & $x$ & $x$ \\
\hline Land reclamation & & & & & & $x$ & & & $x$ & $x$ & $x$ \\
\hline Damming of streams & & $x$ & $x$ & & $x$ & & & & & $x$ & \\
\hline $\begin{array}{l}\text { Inlet consolidation (hard } \\
\text { structures that fix the } \\
\text { position of the inlet) }\end{array}$ & & & $x$ & & $x$ & & $x$ & & $x$ & & \\
\hline Navigational dredging & & $x$ & $x$ & & $?$ & $x$ & $x$ & & & $x$ & $x$ \\
\hline Coastal infrastructure & & $x$ & $x$ & $x$ & & $x$ & & & $x$ & $x$ & $x$ \\
\hline Transport and shipping & $x$ & $x$ & $x$ & $x$ & $x$ & $x$ & & $x$ & $x$ & $x$ & $x$ \\
\hline
\end{tabular}

List of activities adapted from Smith et al. (2016). *Activity is mentioned in informal communications such as newspapers, websites, and so on.

have been converted to golf courses, although the actual locations and environmental impacts have yet to be fully analyzed.

In Morocco, an area of $92 \mathrm{~km}^{2}$ surrounding the Nador lagoon is agricultural, most of which is irrigated (El Yaouti et al., 2008; García-Ayllón, 2017). There is intensive cereal production to the south of the lagoon (Giuliani et al., 2015a), with barley occupying $56 \%$ of total area, olive trees nearly $22 \%$, and other crops approximately 22\%. Fishing activities, agriculture, and livestock production employ up to $46 \%$ of the working population in the region (Najih et al., 2015). There are intensive agricultural activities for vegetables and use of fertilizers (Maanan et al., 2014) in the area surrounding Oualidia lagoon (Morocco), which have expanded in area from 10.52\% in 1946 to $40.15 \%$ in 2006 .

Only $9 \%$ of the watershed for the El Mellah lagoon (Algeria) is agricultural with an area of $7.34 \mathrm{~km}^{2}$, of which $1.30 \mathrm{~km}^{2}$ is dedicated to livestock, mainly cattle and goat production (Melouah, 2013).

The Bizerte lagoon (Tunisia) has a catchment area of $480 \mathrm{~km}^{2}$, of which agricultural activities cover $117 \mathrm{~km}^{2}$ area, with 78 , 34 , and $5 \mathrm{~km}^{2}$ dedicated to cereal culture, horticulture, and arboriculture, respectively (Garali et al., 2009).

The cultivated area around Burullus lagoon (Egypt) has increased by $68.7 \%$, from $231.31 \mathrm{~km}^{2}$ in 1984 to $336,60 \mathrm{~km}^{2}$ in 2015 (Husain et al., 2016). This lagoon receives approximately 4 billion $\mathrm{m}^{3}$ of water per year of drainage water from a catchment area of approximately $403 \mathrm{~km}^{2}$ of the agricultural land in the Nile Delta (El-Amier et al., 2017; Orabi et al., 2017).

\section{Tourism and Recreation}

Lagoons ecosystems are attractive to tourism for both scenic and cultural characteristics. The most popular touristic lagoons in
North Africa are Nador and Oualida in Morocco, Marina, and Marsa Matrouh in Egypt.

In Morocco, the Oualidia lagoon provides many touristic activities including sailing, bathing on beaches, bird watching, and nature watching. The seaside resort has a diversity of landscapes, and in summer, the population increases by $54,000^{1}$ with a daily capacity of 30,000 people. Tourism activities have also been developed around the Nador lagoon, particularly in the northeastern part of the lagoon with new residential complexes, resorts, villas, marinas, restaurants, riads, and a golf academy. This ecosystem has $20 \mathrm{~km}$ of coastline comprising the Boqueronisa and Arkman beaches. The new Med Marchica project aims to provide 101,200 beds and seven marinas and to employ 80,000 people by 2020 .

The Farwa lagoon in Libya is well known for kitesurfing, which attracts tourists during the windy season, from November to March.

The Marsa Matrouh is a coastal lagoon area in Egypt where tourism is expanding. There are 10 beaches that extend for a distance of $7 \mathrm{~km}$, five of them are situated in the lagoon (Abdel, 2015). In summer, up to 450,000 visitors enjoy the attractive, white, sandy beaches and turquoise seawater (Khaled et al., 2014). Because of these ecosystems services, 25 hotels have been established surrounding the lagoon and employ 7,000 workers (Mulazzani et al., 2017).

\section{Extraction of Non-living Resources and Land-Based Industries}

Many lagoons in North Africa are used for extraction of nonliving resources, such as mining activities, and are also associated with industrial areas.

\footnotetext{
${ }^{1}$ www.hcp.ma
} 
Nador lagoon in Morocco has several industrial activities, including mining and metallurgy, such as iron, pyrite, pyrrhotite, and chalcopyrite. The industrial effluent from the Selouane industrial zone is discharged into the lagoon during the wet season (Piazza et al., 2016).

The Bizerte lagoon (Tunisia) has been the site of industrial development since the 1950s. There are industrial complexes of approximately 130 factories located in the towns of Bizerte, Zarzouna, Menzel Abderrahmn, Menzel Jemil, and Menzel Bourguiba. The first and biggest was a cement factory (1950), followed by the "El Fouled" steelworks (1967). Other factories are for metallurgy, electronic industries, textiles, chemical production, petrochemicals including oil refineries, agro-alimentary production, cement manufacturing, and fish processing.

The GCCI (General Company of Chemical Industries) industrial complex is located in the east part of the Farwa lagoon (Libya) at Abu-Kamash. This complex was opened in the 1970s, containing three units with an annual production of 104,000 tons of ethylene dichloride, 60,000 tons of polyvinyl chloride, 50,000 tons of caustic soda, and 45,000 tons of chlorine, as well as the production of sodium carbonate, sodium hypochlorite, and hydrochloric acid (Banana and Mohamed, 2016). These industrial processes also lead to the discharge of mercury into the lagoon ecosystems (Banana and Mohamed, 2016).

\section{Urbanization, Land Reclamation, and Coastal Infrastructures}

Intensive urbanization has occurred around North African lagoons. Essentially, these areas are attractive for both residents and visitors, with increasing land reclamation and construction of a coastal infrastructure, which enables the development of new urban areas. Thus, these regions are now highly populated, with numbers increasing annually.

Over the past 50 years, the population around the Oualidia lagoon (Morocco) has rapidly increased by $240 \%$ from 7,741 inhabitants in 1971 to 18,616 inhabitants in 2014. The expansion of the city has modified some sedimentary forms especially the dunes on the east side of the lagoon (Yamna et al., 2014). However, the most populated lagoon in Morocco is Nador, with an increase in inhabitants from 683,914 to 859,590 between 1994 and $2014^{2}$. Recently, the Moroccan government through the "Marchica agency" has invested 4 billion Euros in seven new projects: Cité Atalayoun, Cité des 2mers, Nador new city, fisherman's village, Baie des Flamants, Marchica Sport, and Les Vergers de Marchica, which are destined as houses, apartments, a harbor, and a research center and natural park for resident and touristic growth; some are constructed already, and some are still under construction.

The inlet located at the center of the Nador lagoon has been modified many times during the last decades (Raji et al., 2013). In 2011, there was an enlargement of the inlet to a width of $300 \mathrm{~m}$ and a depth of $6 \mathrm{~m}$ to improve circulation and shipping. This included the 1,450-m east breakwater and the 1,350-m west breakwater (Daghor et al., 2016).
Monastir lagoon (Tunisia) has been transformed by port structures, marinas, hotels, golf courses, and an airport. This lagoon has been completely drained and has not been included in the list of North African lagoons (Figure 1). Tunis lagoon (Tunisia) is the most urbanized lagoon in North Africa. The population had doubled from 887,803 (2004) to $1,507,000$ inhabitants $(2014)^{3}$. The largest airport in Tunisia (Tunis-Carthage Airport) and military airbase have also been constructed from land reclaimed from the lagoon. Furthermore, the lagoon has been split by the construction of a road "La Goulette," dividing the lagoon into a northerly and a southerly section.

Bizerte lagoon (Tunisia) has four harbors (Harbor of Bizerte, Menzel Abderrahmane harbor, Menzel Bourguiba, and The Carrier bay harbor parked) (Abidli et al., 2016).

Marsa Matrouh is an important city along the $500 \mathrm{~km}$ Mediterranean coast between Alexandria city and the Libyan border in the north part of Egypt. It has 193,000 inhabitants, which represent a density of 0.9 inhabitants $\mathrm{km}^{-2}$ (Khaled et al., 2014). The area has many five-star hotels.

\section{Transport and Shipping}

North Africans societies have used and are still using lagoons for transport and shipping activities by developing harbors and marinas for commercial purposes. The shipping includes oil tankers, passenger cruise liners, packet boats, container ships, and military vessels, as well as smaller boats for artisanal fishing.

In the Nador lagoon (Morocco), the number of "feluccas" for artisanal fishing increased by $30 \%$ from 300 to 390 between 2001 and 2012 .

In the Tunisian lagoon of Bizerte, there were 997 boats in 2010, including 490 fishing boats, and 507 commercial vessels from passenger cruise liners, oil tankers, bulk carriers, container ships, and gas and oil tankers, as well as military vessels. The Menzel Bourguiba harbor receives approximately 542 boats annually including 480 fishing "feluccas", as well passenger cruise liners, commercial ships, ferries, and military vessels. There is also a shipyard that provides shipbuilding, maintenance and painting. The Menzel Abderrahman harbor has approximately 181 artisanal fishing boats (Abidli et al., 2016; Lahbib et al., 2018). The Tunis lagoon has a commercial harbor at RadesLa Goulatte used by 2,902 merchant ships, including "feluccas", passenger cruise liners, packet boats, and container ships (Lahbib et al., 2018). The Boughrara lagoon has 50 "feluccas" in the Boughrara harbor and approximately 100 in Adjim harbor (Lahbib et al., 2018).

The Marsa Matrouh lagoon (Egypt) has 66 "feluccas" with no motors, 6 "feluccas" with outboard motors, and 17 with inboard motors that are used for fishing with trammel nets and long lines. The small "feluccas" contribute $20 \%$ to the fishing activity production, whereas larger boats contribute $80 \%$ within an annual production of approximately 272 tons (Mulazzani et al., 2017). In the Bardawil lagoon, 1,235 "feluccas" of 4 to $6 \mathrm{~m}$ are used for fishing activity. The Burullus lagoon has 2,098 boats where 2,049 are small "feluccas" 
TABLE 2 | The existing pressures on North African lagoons: "X" represents documented and "?" represents undocumented pressures.

\begin{tabular}{|c|c|c|c|c|c|c|c|c|c|c|c|}
\hline \multirow{2}{*}{$\begin{array}{l}\text { Country } \\
\text { Lagoon }\end{array}$} & \multicolumn{3}{|c|}{ Morocco } & \multirow{2}{*}{$\frac{\text { Algeria }}{\text { El Mellah }}$} & \multicolumn{3}{|c|}{ Tunisia } & \multirow{2}{*}{$\begin{array}{l}\text { Libya } \\
\text { Farwa }\end{array}$} & \multicolumn{3}{|c|}{ Egypt } \\
\hline & Khenifiss & Oualidia & Nador & & Bizerte & Tunis & Boughrara & & Marsa Matrouh & Burullus & Bardawil \\
\hline \multicolumn{12}{|l|}{ Pressure } \\
\hline Smothering & & & & & $x$ & $x$ & & & & & $x$ \\
\hline Substratum loss & & & & & & $x$ & & & & & $x$ \\
\hline Changes in siltation & & $x$ & $X$ & & & $x$ & & & $x$ & $x$ & \\
\hline Abrasion & & & $x$ & & $X$ & $x$ & & $x$ & & & $x$ \\
\hline Selective extraction of non-living resources & & $x$ & $x$ & & & & & & & $X$ & $x$ \\
\hline Presence of underwater noise & $x$ & $x$ & $x$ & $x$ & $x$ & $x$ & $x$ & $x$ & $x$ & $x$ & $x$ \\
\hline Presence of litter & & & & & $X$ & $x$ & $x$ & & & $X$ & \\
\hline Thermal regime change & & $x$ & & & $X$ & $x$ & $x$ & & $x$ & $x$ & $x$ \\
\hline Salinity regime change & & & $X$ & & $X$ & $x$ & $x$ & & $x$ & $X$ & $x$ \\
\hline Introduction of synthetic compounds & & $x$ & $x$ & $X$ & $X$ & $x$ & & & $x$ & $X$ & $x$ \\
\hline Introduction of non-synthetic compounds & & $x$ & $X$ & $X$ & $X$ & $x$ & $x$ & $x$ & $x$ & $X$ & $x$ \\
\hline Introduction of radionuclides & & $x$ & & & & & & & & $x$ & $x$ \\
\hline Introduction of other substances & & $x$ & $x$ & $x$ & $X$ & $x$ & $x$ & $x$ & & $X$ & \\
\hline Nitrogen and phosphorus enrichment & & $x$ & $x$ & $x$ & $x$ & $x$ & $x$ & $x$ & $x$ & $x$ & $x$ \\
\hline Input of organic matter & & $x$ & $x$ & $x$ & $X$ & $x$ & $x$ & $x$ & $x$ & $x$ & $x$ \\
\hline Introduction of microbial pathogens & & $x$ & & $x$ & $X$ & $x$ & $x$ & & & $X$ & $x$ \\
\hline $\begin{array}{l}\text { Introduction of non-indigenous species and } \\
\text { translocations }\end{array}$ & & $x$ & $x$ & & & & $x$ & & & & \\
\hline Selective extraction of species & & & & $x$ & $X$ & $x$ & $x$ & & & & $x$ \\
\hline Death or injury by collision & & $x$ & $x$ & $x$ & $?$ & & & & & $X$ & \\
\hline Barrier to species movement & & $x$ & & & $X$ & $x$ & & & & & \\
\hline Water ?ow rate changes & & $x$ & & & $?$ & $x$ & $x$ & & $x$ & & $x$ \\
\hline $\mathrm{pH}$ changes & & $x$ & & & & $x$ & $x$ & & $x$ & $x$ & $x$ \\
\hline Change in wave exposure & & & & & & & & & $x$ & & \\
\hline
\end{tabular}

List of pressures adapted from Smith et al. (2016).

(4-6 m), 41 are medium boats $(6-8 \mathrm{~m})$, and eight are large boats $(>8 \mathrm{~m})$.

\section{Pressures on North African Lagoons}

In the context of North African lagoons, there are multiple pressures that have different forms originating from the variety of economic activities (Tables 1, 2). The distribution of these pressures among the 11 selected lagoons is shown in Table 2, and more details about specific pressures are described below.

\section{Pressures From Agricultural Effluents}

Agriculture in the drainage basins along the coast of North Africa is responsible for contaminating lagoons with agrochemicals such as fertilizers, pesticides, and herbicides. Additionally, there are pressures from the manure derived from animal rearing.

The main pressure from the high nutrient inputs to the Oualidia lagoon in Morocco is from surface and groundwaters that drain from the cultivated areas that cover $78 \%$ of the catchment (Damsiri et al., 2015, 2017) and where nitrogen and phosphate fertilizers are applied (Maanan et al., 2014). These nutrients promote a significant increase in chlorophyll $a$ within the lagoon ecosystem (El Asri et al., 2017a). Another Moroccan example of pressures from agrochemicals is an irrigated agricultural area of $92 \mathrm{~km}^{2}$ around the Nador lagoon (Re and Sacchi, 2017).
In the case of Algeria, many studies describe the effect of agricultural pollutants and livestock manure (Nadira, 2008) from the two rivers "R'kibet and El Mellah" (Chaoui et al., 2006; Magni et al., 2015) on fish, mollusks, and crustaceans (Mebarki et al., 2015) in the El Mellah lagoon.

The pressure from runoff draining the agricultural areas around Bizerte lagoon (Tunisia) increases with rainfall in winter. Runoff contains various contaminants and pollutants including nutrients, pesticides and heavy metals (Kamel et al., 2014). The increase in nutrient concentrations, especially during the wet season, stimulates phytoplankton blooms (Béjaoui et al., 2017).

One of the most heavily polluted lagoons in North Africa is Burullus on the Nile delta in Egypt. Nutrient, pesticide, and metal inputs come from eight streams and a canal draining from the adjacent watershed (Orabi et al., 2017). In the southern area, there are high concentrations of tin (144 ppm) and of arsenic (44 ppm), far exceeding the World Health Organization guidelines for arsenic in soil (1.5 ppm) (El-Monsef et al., 2017).

\section{Pressures From Extraction of Living Resources}

There are multiple pressures from the extraction of living (e.g., fishing, shellfish harvest) and non-living resources (e.g., dredging and quarrying for sand). These result in selective extraction of species, death or injury of fauna, introduction and translocation of non-indigenous species, substratum loss, 
abrasion and resuspension of sediment, smothering, nutrient mobilization, and underwater noise (Table 2).

The Oualidia lagoon is an ecosystem with high pressure from the extraction of living and non-living resources such as traditional fisheries (fish and molluscs), oyster aquaculture (Bocci et al., 2016), seaweed harvesting, and sand extraction (Beryouni et al., 2012; Maanan et al., 2014; El Asri et al., 2015). These activities have led to pressures such as input of organic matter from aquaculture and blooms of phytoplankton (Damsiri et al., 2017). Nador lagoon is also known for its aquaculture activities and fishing. The use of small mesh sizes has exerted a pressure on the fish population.

There are pressures on El Mellah lagoon (Algeria) from aquaculture with organic matter enrichment of sediment (Embarek et al., 2017).

Pressures on the Boughrara lagoon (Tunisia) include organic matter from the introduction of non-indigenous species, such as the invasive species polychaete Branchiomma bairdi McIntosh (1885), which settles in high densities (up to $35 \mathrm{~m}^{-2}$ ) on buoys and hulls of vessels (Khedhri et al., 2017b).

There is little information about Farwa lagoon (Libya). However, one resulting pressure of the fishing activity is underwater noise pollution (Essghaier et al., 2013).

The fishing, harvesting, and aquaculture extraction of living resources from Bardawil lagoon (Egypt) exert significant pressures on this ecosystem (i.e., overfishing).

\section{Pressures From Urban and Industrial Effluents}

There are three types of effluent affecting lagoons including (i) urban sewage untreated or through a wastewater treatment plants (WWTP); (ii) urban wet weather discharges including rainwater, runoff water, and discharges from separated stormwater system outfalls resulting from rainfall in an urbanized catchment; these flow into the lagoons without passing through a wastewater treatment system (Gooré et al., 2015); and (iii) the industrial effluents through a local or common WWTP. These pressures increase from both urban growth and climate change effects and can lead to a state change by contamination and pollution.

Some of the lagoons (Nador in Morocco, El Mellah in Algeria, Tunis in Tunisia, and Burullus in Egypt) are enriched with nutrients from agriculture (Table 1), but there are additional pressures from urban and industrial effluents (Oczkowski et al., 2008; Tlig-Zouari and Maamouri-Mokhtar, 2008; Nassar and Gharib, 2014; Alves Martins et al., 2015; Derradji et al., 2015; Bocci et al., 2016; Daghor et al., 2016; Hammani et al., 2016; El Asri et al., 2017b; El-Zeiny and El-Kafrawy, 2017; Khedhri et al., 2017a).

The increasing tourist development activities around lagoons in North Africa have also increased pressures from domestic effluents due to the seasonal increase of population, especially during the summer.

Oualidia lagoon (Morocco) is located between two cities "El Jadida" and "Safi," adjacent to one of the biggest phosphate mines in the world and fertilizer plants. Indeed, the surface water of the lagoon is phosphate enriched (Damsiri et al., 2017). Furthermore, this lagoon is known also for touristic activities and a population increase by a factor of four times during summer time. This overwhelms the capacity of the WWTP, increasing the nutrient pressures. The WWTP of Nador city was built in 1980 and expanded in 1990, but it has become inadequate due to urban growth (Ruiz et al., 2006). Two new WWTP were constructed in 2010; the Grand Nador WWTP is an activated sludge plant with a daily treatment of $14,000 \mathrm{~m}^{3}$, and El Aroui WWTP is a natural lagoon with a treatment capacity of 2,500 $\mathrm{m}^{3}$ per day. These treatment plants are undersized; thus, there are pressures from effluent into the lagoon, as well as anaerobic microbial degradation (Giuliani et al., 2015b). Furthermore, there is industrial effluent coming from the Selouane industrial area that is discharged into the lagoon during the wet season. The pressures from industrial effluent (Nador lagoon) include inputs of pollutants, such as polychlorinated biphenyls (PCB), polycyclic aromatic hydrocarbons (Giuliani et al., 2015b), and increasing inputs of polybrominated diphenyl ethers (Piazza et al., 2016).

The effluent from industries around Bizerte lagoon (Tunisia) has only primary wastewater treatment (Barhoumi et al., 2014; Hammani et al., 2016). SACEM (electrical transformers) uses 900 tons of PCB (Barhoumi et al., 2014). These activities have led to chemical contamination of mussels (Barhoumi et al., 2014).

The Tunis lagoon is vulnerable to pressures from industrial effluent and domestic sewage due to the doubling of the local resident population during the last 10 years.

Marsa Matrouh lagoon (Egypt) is contaminated by pressures from metal pollution (Abdel, 2015) and inadequate sewage treatment due to high tourist influx (Gharib et al., 2011).

\section{Pressures From Civil Engineering Projects}

Infrastructure for the management of the lagoons' ecosystems includes artificial channels for maritime navigation of harbors and ports. Examples include the modification of inlets at Moulay Bousselham and Nador in Morocco, El Mellah in Algeria, Boughara in Tunisia, and Bardawil in Egypt.

Nador lagoon (Morocco) has had a new inlet since 2011 that was made to increase water exchange with the sea (Bocci et al., 2016). Most of the modern centers of Tunis city have been built on land reclaimed from the Tunis lagoon (Thornton et al., 1980). A comparison between aerial photographs and topographic maps produced between 1902 and 2002 shows the pressures of coastal infrastructure and the expansion of the city at the northern and southern limits of the lagoon (Chouari, 2015). The eastern inlet (El Kantra Channel) of Burullus lagoon (Tunisia) has been enlarged from a narrow passage of $12.5 \mathrm{~m}$ across in 2004 to $160 \mathrm{~m}$ in 2007. This has increased the daily water exchange with the sea from 0.8 million $\mathrm{m}^{3}$ to 6.9 million $\mathrm{m}^{3}$ per day (DGPA, 2001). The choking of the inlets in Bardawil lagoon (Egypt) has led to pressures such as siltation of the ecosystem that has increased significantly. It has also changed the water exchange between the sea and the lagoon, causing sedimentation at the entrance to the inlets (Nassar et al., 2018).

\section{Pressures From Transport and Shipping}

Pressures from transport and shipping activities were found in all North African lagoons. These include (i) underwater noise from motorized ferries, vessels, and yachts; (ii) hydrocarbons from accidental oil spills from motorized boats; and (iii) 
antifouling agents that are based on organic diluters mixed with highly concentrated toxic metals such as copper and zinc (Guerra-García and García-Gómez, 2005) or tributyltin (TBT) compounds.

These multiple pressures often result from conflicting interests among stakeholders, as well as from previous development and management measures for the lagoons (Lillebø, 2015). The pressures (Table 2 ) result in a state change of the environment such as symptoms of eutrophication in the lagoons (e.g., Nador in Morocco, Bizerte and Tunis in Tunisia, Bardawil in Egypt). These changes affect ES (Newton et al., 2018) and can lead to an impact on human welfare.

\section{State Change in North African Lagoons}

Human activities and modifications to North African lagoon ecosystems and their catchment areas have resulted in increased pressures that have modified the state of these ecosystems. The change of state can be at the environmental, ecological, and/or ecosystem level. Table 3 shows the state changes in lagoon ecosystems (components and processes), intermediate services (supporting and regulating services), and the final ES (provisioning, regulating, and cultural) of the lagoons. No state changes have yet been detected for the protected Khenifiss lagoon, an almost pristine lagoon.

The changes to the inlets of Nador lagoon (Morocco), especially the most recent ones in 2011, have altered the hydrological processes and nutrient condition of the ecosystem. Eutrophication has stimulated algal blooms of Caulerpa prolifera, Gracilaria bursa-pastoris, and Colpomenia sinuosa. These changes have modified the state of ES components, intermediate services, and regulating and supporting services, as well as final ES (El Asri et al., 2017c).

The environmental state of El Mellah lagoon (Algeria) has been degraded by the presence of contaminants and pollutants, such as heavy metals and neurotoxic pesticides (Benradia et al., 2016). The application of pesticides from agricultural activities and pressures from inputs of organophosphates affects the ecological state of the benthos, for example, the toxic effect of malathion on clams (Nadji et al., 2010). As this is a species of economic value, the delivery of provisioning ES has declined. Furthermore, the change in salinity, due to aquaculture activities, has caused a decline in bird species diversity (2013-2017) degrading cultural services, such as bird watching (Telailia et al., 2017).

The intensive use of fertilizers on agricultural activities in the catchment area of Bizerte Lagoon (Tunisia) has modified an intermediate service through increased pressures from high inputs of nitrogen and phosphorus that have altered the state of nutrient condition and the state of phytoplankton biomass and primary production (Béjaoui et al., 2017), especially in the inner part of the lagoon. Another state change is in the hydrography and water cycling (intermediate service) of the Bizerte lagoon with an estimated deficit of $-7.5 \mathrm{Mm}^{3}$ of the lagoon's annual water flowing into the Mediterranean sea (Béjaoui et al., 2017).

The subsidence land rate around Tunis lagoon (Tunisia) is $22 \mathrm{~mm}_{\text {year }}{ }^{-1}$, which may lead to state change through marine submersion and flooding hazards (Ennesser et al., 2011). The enlargement of the eastern inlet of Boughrara lagoon (Tunisia) has not improved the environmental state or ecological state. Harmful algal blooms (HAB) have increased organic matter accumulation and stimulated the growth of the polychaete population (Khedhri et al., 2017a), changing the state of regulating and supporting services.

Pressures from the industrial wastewater of a chemical company have affected the environmental state of Farwa lagoon (Libya) that has been highly contaminated by mercury, during the period January to August 2014 (Banana and Mohamed, 2016). Marine flora (fish, cuttlefish, and oyster) and fauna of the lagoon have been contaminated as high concentrations of mercury were found in different species (Banana and Mohamed, 2016), impacting the provisioning and regulating services.

The Egyptian lagoons are the most affected by human activities, and resulting pressures have led to significant changes in their state of environment. For instance, the large increase of water inflow from agricultural freshwater drainage (from $81.7 \%$ in 1971 to $98.18 \%$ in 2003 ) has changed the hydrological state of Burullus lagoon (El-Adawy et al., 2013). The decrease in the environmental state of salinity has led to a change in intermediate services and final ES. The provisioning services of total marine fish decreased from 15.99 to $1.81 \%$ by weight (El-Adawy et al., 2013). Inflow of contaminants changed the state of Burullus lagoon (Orabi et al., 2017), where symptoms

TABLE 3 | The state change in North African lagoons: "X" represents documented and "?" undocumented state change.

\begin{tabular}{|c|c|c|c|c|c|c|c|c|c|c|c|c|}
\hline \multirow{2}{*}{$\begin{array}{l}\text { Countries } \\
\text { Lagoon }\end{array}$} & & \multicolumn{3}{|c|}{ Morocco } & \multirow{2}{*}{$\frac{\text { Algeria }}{\text { El Mellah }}$} & \multicolumn{3}{|c|}{ Tunisia } & \multirow{2}{*}{$\begin{array}{l}\text { Libya } \\
\text { Farwa }\end{array}$} & \multicolumn{3}{|c|}{ Egypt } \\
\hline & & Khenifiss & Oualidia & Nador & & Bizerte & Tunis & Boughrara & & Marsa Matrouh & Burullus & Bardawil \\
\hline \multicolumn{13}{|l|}{ State change } \\
\hline \multirow[t]{2}{*}{ Lagoons ecosystems } & Components & & $x$ & $x$ & $x$ & $x$ & $x$ & $x$ & $x$ & $x$ & $x$ & $x$ \\
\hline & Processes & & $x$ & $X$ & $x$ & $X$ & $x$ & $x$ & $?$ & $X$ & $x$ & $x$ \\
\hline \multirow[t]{2}{*}{ Intermediate services } & Supporting & & $x$ & $X$ & $x$ & $x$ & $x$ & $x$ & $?$ & $x$ & $x$ & $x$ \\
\hline & Regulating & & $x$ & $X$ & $x$ & $x$ & $x$ & $x$ & $?$ & $x$ & $x$ & $x$ \\
\hline \multirow[t]{3}{*}{ Final ecosystem services } & Provisioning & & $x$ & $X$ & $x$ & $X$ & $x$ & $x$ & $x$ & $X$ & $x$ & $x$ \\
\hline & Regulating & & $x$ & $x$ & $x$ & $x$ & $x$ & $x$ & $x$ & $x$ & $x$ & $x$ \\
\hline & Cultural & & $?$ & $?$ & & $?$ & $x$ & $x$ & $?$ & $x$ & $x$ & $x$ \\
\hline
\end{tabular}

These are based on Elliott et al. (2017) ES classification. 
of microbial anaerobic degradation have been observed from agricultural input (Giuliani et al., 2015a). A further, devastating pressure is the destruction of the dune barrier system to use the sediments for reclamation purposes (El-Asmar et al., 2013). Marsa Matrouh lagoon (Egypt) is contaminated by metals (Abdel, 2015) and domestic sewage (Gharib et al., 2011) that promote phytoplankton blooms.

Sedimentation in front of the inlets of Bardawil lagoon (Egypt) has changed the environmental state by restricting the exchange of water between the sea and the lagoon (Nassar et al., 2018), which could lead to changes in the provisioning of final ES such as fishing activities. Meanwhile, the ecological state has changed because of overfishing pressures during recent decades. For instance, the crab landings increased from 754.2 tons in 2000 to 2,053.1 tons in 2009 and then decreased to 518.7 tons in 2014, followed by an increase to $1,973.4$ tons in 2015, which represents $42 \%$ of total production. There are also changes in ecological state due to a new invasive species of crab, Callinectes sapidus (Abdel Razek et al., 2016), which affects nets and netted fish. The armored dinoflagellate Alexandrium species, which is a toxic species, now accounts for $17 \%$ of total Dinophycae taxa (El-Kassas et al., 2016).

The environmental state of sediments in Marsa Matrouh lagoon (Egypt) has deteriorated with contamination and pollution from the trace metals vanadium, aluminum, tin, arsenic, and selenium (Abdel, 2015). This deterioration in sediment quality affects the regulating and provisioning final ES; for example, high concentrations of aluminum $\left(100 \mu \mathrm{g} \mathrm{g}^{-1}\right.$; wet weight) have been observed in the fish Pagellus erythrinus and may damage its liver (Abdel, 2015).

\section{Impact (on Human Welfare) in North African Lagoons}

Human activities and resulting pressures that cause the degradation of the environmental state, the ecological state, and the delivery of ES of coastal lagoons may ultimately impact on human welfare (Table 4). For example, lagoons are nursery habitats for juveniles of commercial species; therefore, changes in the state of the environment and ecology lead to a loss of this nursery service that supports fisheries and thus provisioning ES. Impacts on human welfare are detected in most of the North African lagoons, except the Khenifiss lagoon (Morocco), which is not impacted at present. Other impacts result from toxins in $\mathrm{HAB}$ and the contamination of seafood by chemicals.

Civil engineering and infrastructures that modify the connectivity of most of the lagoons in the study can change the wave exposure on part of the shoreline and cause erosion. This can lead to negative impacts on the shoreline protection of the lagoon with an increased risk of flooding or storm damage to the human population due to the erosion or removal of sediment, which can aggravate conflicts among stakeholders (Conde et al., 2019; Table 4).

The Marsot aquaculture activities in Nador and Oualidia lagoons (Morocco) started in 2005 but ceased in 2010 due to environmental problems. This impacted local jobs and the availability of seafood. The presence of highly persistent pollutants, such as PCB and PAH in Nador lagoon (Morocco), has contaminated seafood and is a risk to human health (Giuliani et al., 2015a). The harvesting and selling of oysters from the breeding site of Oualidia lagoon were prohibited in March 2017 by the Department of Marine Fisheries of Morocco (Huffpostmaghreb, 2017) because of possible impacts on human health. The welfare of fishers of Nador lagoon was impacted by the loss of catches, leading to protests in 2018.

The degradation of environmental state due to organic overenrichment of sediments of El Mellah lagoon (Algeria) has decreased the biodiversity and the availability of seafood in some areas, especially during the summer of 2015 (Magni et al., 2015).

The pollution in Bizerte lagoon (Tunisia) affects not only the aquatic organisms but also impacts human health. For example, the mollusc disease "Marteiliosis" that is caused by the protozoan parasite Marteilia species has infected Mytilus

TABLE 4 | Summary of Impacts on human welfare in North African lagoons: "X" represents documented and "?" undocumented impacts on human welfare.

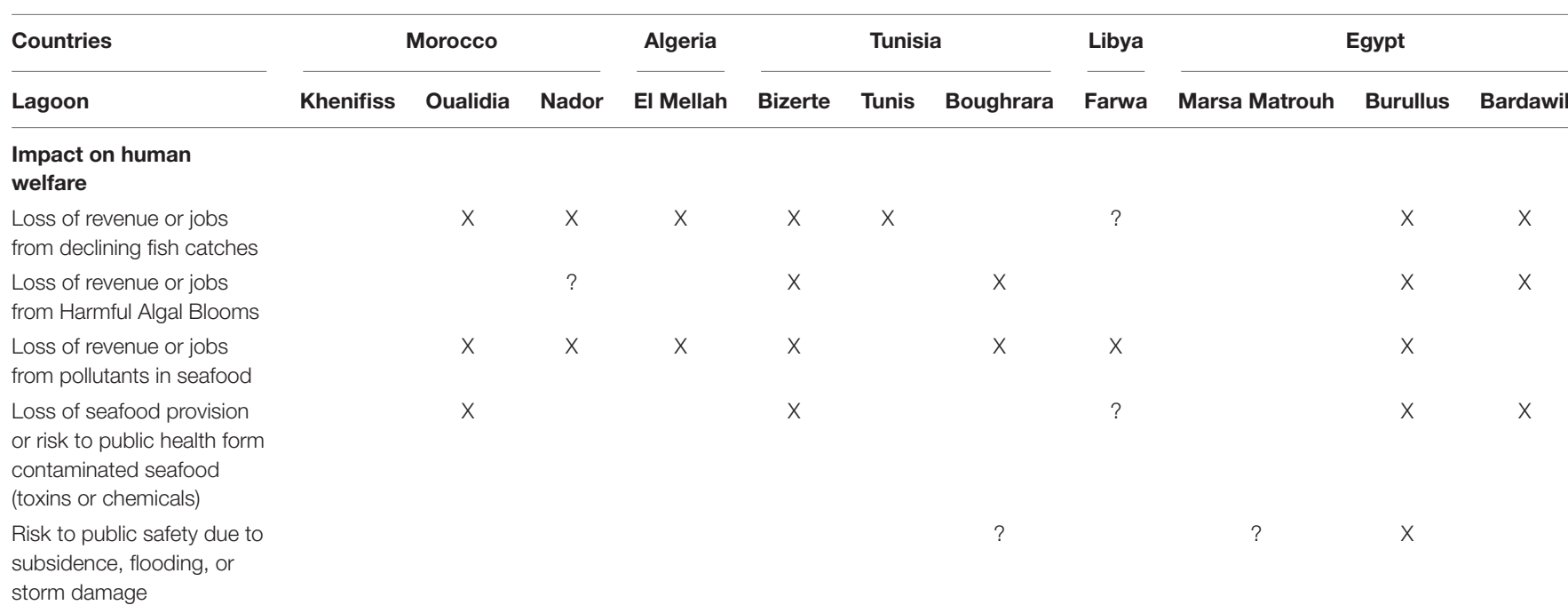


galloprovincialis, which has impacted provisioning services of a commercial species (Elgharsalli et al., 2016). Furthermore, the high concentrations of TBT in seafood, such as commercial species of bivalves ( $R$. decussatus, C. glaucum, P. nobilis, and M. galloprovincialis), have impacted both revenues and seafood provision (Abidli et al., 2016).

The increased loading of organic matter and the presence of $\mathrm{HAB}$ in Boughrara lagoon (Tunisia) have caused high fish mortality and thereby an impact on food provisioning (Khedhri et al., 2017b).

The mercury contamination from the GCCI company detected in the fish, oysters, and cuttlefish in Farwa lagoon (Libya) may represent a health risk to people living in the area (Kim et al., 2016; Ha et al., 2017).

The high concentrations of metals detected in fish from Marsa Matrouh lagoon (Egypt) impact both the provision of seafood and are a risk to human health (Abdel, 2015).

The chemical pollutants and salinity changes in Burullus lagoon (Egypt) have had an effect on fish diversity that has declined from 32 to 25 species (Fadili et al., 2016). This impacts the provision of commercial fish species (El-Zeiny and ElKafrawy, 2017) to people living in the region (Orabi et al., 2017). Furthermore, modifications to the inlet can increase the recession rates of the shoreline, which impacts the security of the inhabitants by decreasing the sea defenses (supporting service) and their livelihoods from tourism revenue (cultural service) (Nassar et al., 2018).

The revenues from fisheries in the Bardawil Lagoon (Egypt), food provision, and public health are threatened by HAB (Abdel Razek et al., 2016; El-Kassas et al., 2016).

\section{DISCUSSION}

North African lagoons provide many supporting, regulation, provisioning, and cultural services. Nevertheless, they are subject to numerous activities that represent sources of conflict among the different users (Newton et al., 2014; Dolbeth et al., 2016; Newton and Elliott, 2016; Lillebø et al., 2017) producing multiple pressures that represent a negative state change on the environment and impact human welfare.

Most drivers, activities, pressures, state change, and impacts (on welfare) in North African lagoons are similar to those identified in European lagoons (Newton et al., 2014; Dolbeth et al., 2016), because of similar activities and behavior of the stakeholders using lagoons ecosystems.

There have been several, past management responses in North Africa aimed at reducing nutrient and phosphorus enrichment, protection of the aquatic resources, and developing environmental regulation to control aquaculture industries in the lagoons. These include building sewage treatments plants, improving aquatic resources, providing technical support, and monitoring and scientific research.

\section{Past Management Measures}

The construction of domestic sewage treatment plants has been the main management measure in the past. Nevertheless, sewage treatment is still non-existent or inadequate for many North African lagoons.

Morocco launched a National Plan of Sanitation in 2005. As a result, Nador lagoon has two UWWTP, Moulay Bousselham and Oualidia have one, but Sidi Moussa has none. Morocco also created the National Agency for Aquaculture Development in 2011, which has developed environmental measures that should be followed by the aquaculture industries. The National Agency for Aquaculture Development is the leading actor for the aquaculture industry to promote the development of sustainable aquaculture along the Moroccan coast, including lagoons.

Algeria built a UWWTP behind El Mellah lagoon, but the water quality is still poor with respect to fecal microbes (Kherifi and Bousnoubra-Kherici, 2016). There is an unresolved conflict between the managers of the El Kala National Park and the inputters to this lagoon, mainly industries and farmers (Telailia et al., 2017).

Urban WWTP were built in the lagoons of Bizerte, Tunis, Boughrara, and Ghar El Melh (Tunisia) because of sewage contamination. Tunis lagoon was the worst affected by the contamination, but there was a restoration project in 1985 to stop pollution and eutrophication (Vandenbroeck and Rafik, 2001), and the conditions were improved by collecting waste and algae around the margin and dredging. However, the longterm monitoring plan has not been continuously maintained for nutrients and total suspended solids, but only for water temperature and salinity. Nevertheless, it highlighted sudden meteorological events (rainfalls) and/or unpredictable accidental pollution (Trabelsi et al., 2013).

No data about environmental management responses in Libya have been found in this study.

The Ministry of Environment of Egypt updated the National Biodiversity, Strategy and Action Plan for the years 2015-2030 (Temraz et al., 2016). This includes wetland habitats in Egypt. The targets are to reduce the rate of wetland loss by $50 \%$ by 2021 , improve water efficiency in farming by $50 \%$, and develop inland water ecosystems (Finkl, 2017).

\section{Policy Instruments With Respect to North African Lagoons}

North African lagoons are important at the local, national, and regional scale to achieve sustainable development. Regulatory authorities are responsible for monitoring programs to protect biodiversity and ES of the lagoons. This can be achieved by policy instruments to protect these ecosystems.

At the national level, Morocco implemented new legislation (Conseil Economique, Social et Environnemental, 2014) in 2014 for the protection of coastal areas, without a specific mention of lagoons. For instance, the law prohibits building on a strip of land $100 \mathrm{~m}$ wide, adjacent to the shoreline. The new law also prohibits the discharge of wastewater, waste, and any pollutants in the coastal area without specific authorization and respecting specific limits for discharges (Conseil Economique, Social et Environnemental, 2014). Another law that is under development calls for the conservation of fisheries ecosystems and the protection of the marine environment against pollution 
(Secrétariat Général du Gouvernement Marocain, 2017). Morocco has created a special planning agency for the Nador Lagoon, the Agence d'Amenagement de la Marchica.

In 2002, Algeria passed legislation (Journal Officiel de la Republique Algerienne, 2002) for the protection and development of the coastal areas. The law includes lagoons as ecosystems, but uses the term "lido," which can be confused with coastal lakes.

Tunisia has created a special agency, named Agence de protection et d'aménagement du littoral ${ }^{4}$, for the planning and the protection of coastal areas including lagoons.

Libyan authorities issued legislation (no. 14) for marine protected areas in 1992 that specifies sites that include lagoons, based on the biological, physical, and socioeconomic universal criteria (Haddoud and Rawag, 1995).

The Egyptian environmental affairs agency implemented Law 4 for the protection of the environment Amended by Law 9/2009 (Egyptian Environmental Affairs Agency, 2009) to ensure the environmental protection in coastal zones as an Integrated Environmental Management of Coastal Zones without defining lagoons specifically but including them within wetlands.

At the Mediterranean region scale, there are a number of policies relevant to lagoons in the context of the management of coastal areas. These include the Ramsar convention for wetlands; the Barcelona Convention (1975) aimed at the protection of the marine environment and the coastal region of the Mediterranean; and the Integrated Coastal Zone Management "ICZM" Protocol signed by most Mediterranean countries, except Egypt and Libya. The action plan for the ICZM protocol was implemented for the period 2011-2019, to strengthen capacities for the use of ICZM policies, instruments, tools, and processes, as well as promoting the protocol within the region and worldwide.

At the global level, the United Nations defined 17 Sustainable Development Goals (SDGs) and 244 indicators to be met individually and collectively by the signatory states, including North African countries (UN, 2015). Four SDGs are relevant to lagoon ecosystems both directly and indirectly. The most relevant to lagoons is SDG 14 "Life below Water" followed by SDG 6 "Clean Water and Sanitation," The SDG 15 "Life and Land," and the SDG 13 "Climate Action."

\section{Options for Management Measures}

Identifying the sensitive and vulnerable zones in the lagoons allows managers to prioritize immediate measures for water bodies at risk (Ferreira et al., 2006). This knowledge also allows managers to protect specific habitats, such as seagrass beds, and specific, keystone species that provide supporting and provisioning ES (e.g., food).

Once the management options have been identified, these should be checked to see whether they follow the 10-tenet approach (Elliott, 2013; Barnard and Elliott, 2015; Elliott et al., 2017), to be both successful and sustainable. The measures should include both short- and long-term plans that can deliver immediate, positive results, as well as mitigate and prevent future issues. One of the main short-term measures is the construction of UWWTP in some lagoons, for example, Farwa and Ain

${ }^{4}$ http://www.apal.nat.tn/site_web/index.html
Zaina in Libya and Sidi Moussa in Morocco. The capacity of existing UWWTP is insufficient because of the seasonal increase of population due to visiting tourists. This occurs mainly summer when temperatures are high and oxygen solubility is low. Existing UWWTP can be increased in capacity or upgraded from primary to tertiary treatment, for example, Oualidia and Tunis lagoons, and the installation of nutrient removal ponds using plants such as reed beds. These measures will reduce the organic and nutrient loading into the lagoons and improve their oxygen conditions to mitigate future eutrophication. As the Mediterranean climate is hot and dry in summer, eutrophication increases during the summer and algal proliferation reaches its maximum. Effluent from UWWTP can be reutilized as a fertilizer for some crops, for example, fruit trees. The use of UWWTP effluent for irrigating lawns and golf courses can improve the sustainability in arid countries.

Another possible management measure is the construction of belt canals around the lagoons within small areas in order to intercept and divert rainwater and agricultural runoff. Moreover, increasing green areas in cities and villages and constructing uncemented cobblestone roads instead of concrete-asphalt streets can help increase the infiltration rate of rain into the soil (Rocheta et al., 2017).

Additional management measures can be implemented to restore water and sediment fluxes, especially for the lagoons with dams in the catchment and/or with inlet modifications, for example, Moulay Bousselham in Morocco, Bizerte and Boughrara in Tunis, and Marina in Egypt.

Another effective measure is monitoring and protecting surface water and groundwater from pollution sources surrounding the lagoon. This includes protecting water resources from excessive extraction, as well as contamination and pollution from runoff of agrochemicals, industrial effluents and emissions.

Management measures to reduce litter include conveniently located bins, environmental notices targeting the tourists, litter collection, and cleaning of lagoon beaches in summer, for example, Marsa Matrouh in Egypt and Oualidia and Nador in Morocco.

Land subsidence and increased risk of flooding in the area surrounding the lagoon can be avoided by an urbanization and land use plan to avoid overconstruction and establish setback lines, for example, Tunis lagoon.

Different types and intensity of monitoring programs, surveillance operational and investigative monitoring (EU, 2000), can be implemented as a response to different risks. The monitoring plans should consider seasonality and hydrological, physiochemical, biological, and ecological aspects of the lagoons, and not focus on only one aspect, such as the concentration of a pollutant.

Awareness raising campaigns, especially for the inhabitants of the lagoon area, can be very effective. Managers can work with the local schools to organize educational field trips around the lagoons. The research group for the protection of birds in Morocco previously organized guided tours for individuals, local associations, and local schools in the Oualidia lagoon to educate and raise awareness regarding the importance of lagoons ecosystems. During 2017, 1,863 students and 
professors were introduced to the value of lagoons by this research group ${ }^{5}$.

Conflict management can be improved by organizing a stakeholder forum with timely stakeholder consultation to reach agreement on how to manage these ecosystems (Newton and Elliott, 2016). In Nador lagoon (Morocco), civil society confronted the Marchica development project, which led to protesters questioning administration decisions regarding the prohibition of access to certain sites, the protection of local properties, and the inclusion of management processes.

Measures to protect culturally important areas are essential to reduce conflict between the local community and visitors. Crosscultural sensitivity is necessary to maintain respect for local cultures and populations (e.g., typical seafood such as "Mussel Tagine," and typical design of traditional boats). Cultural erosion can be mitigated through cultural adaptation, for example, using traditional boats for tourism around the lagoon. The gondolas of Venice lagoon are an example of this, as are the moliceiros of Aveiro lagoon.

Economic instruments (fines, taxes, subsidies) can also be used in management. The "polluter pays" principle advocated by the OECD can be used so that economic sectors are held to account if they exceed emission standards, especially for pollutants. Aquaculture, textile, and oil industries are all examples of polluters within these lagoon systems.

A policy response focused on the lagoons ecosystems may result in new regulations to reduce the impact of activities and pressures from the surrounding areas.

Supporting sustainable investment by lowering taxes in order to balance economic growth, environmental awareness and actions, food security, and social development can lead to new blue economy activities such as bioagriculture, ecotourism, ecological shipping, and organic aquaculture. This could ensure an increase in blue growth related to North African lagoons.

\section{Confusion About Nomenclature of Lagoons in the Context of North African Lagoons}

The terminology used for coastal lagoons is extremely varied throughout the world, and it hampers the transfer of knowledge (Newton et al., 2014). The vocabulary also changes among North African countries even if they are using the same language (Arabic, Amazigh, and the two official foreign languages, French in Morocco, Tunisia and Algeria, and English in Libya and Egypt). "Lagune" is the most common French term used in Maghreb countries. Moroccan Arabic dialect includes "Merja" as in Merja Zerga Moulay Bousselham and sometimes the term "sebkha." Others names include "Mar Chica" for Nador lagoon, a remnant of Spanish colonization. In Algeria, "Lac," which means lake, is used, for example, "Lac El Mellah," and also "Ildo" for coastal lakes. Tunisia also uses the French term "lac" such as "lac de Tunis," "lac Bizerte." "Bouhaira" is the Arabic term. Farwa "Island" is the term used for "Farwa lagoon" in Libya or "Jazirat Farwa," which means an island. The term "Bouhaira" is used in most of the Egyptian lagoons, "Bihira" in the eastern part and

\footnotetext{
${ }^{5}$ http://www.grepom.org/wp-content/uploads/Rapport-annuel-_Activité_ Centre-Walidia_2017.pdf
}

sometimes using even "Bouhaira El Malha," which means "Salted lake," but in English, lagoons are still referred to as "lake" such as Burullus or Manzala lake. Moreover, Libya has used "lagoon" for four ecosystems, of which only two can be considered lagoons as Ain Ghazala and El Burdi are coastal inundations.

\section{Knowledge Gaps in North African Lagoons}

The analysis carried out in the present study revealed the lack of interdisciplinary studies on lagoons. Most studies are in specific areas, mostly in natural sciences such as biological, physicochemical, environmental, and hydrological studies with a few geological studies (Ayache et al., 2009; Flower et al., 2009; Ramdani et al., 2009b; Thompson et al., 2009; Raji et al., 2018).

North African countries need targeted but interdisciplinary studies about coastal lagoons to provide more information and knowledge in order to better understand the issues and provide more appropriate management measures. For instance, Libya has some literature reviews completed through international collaboration (Essghaier et al., 2013; Mahmoud Khamis and ElSayed El-Sayed, 2015; Banana and Mohamed, 2016), but lacks a governmental platform to provide data about the lagoons.

More data are needed for all North African lagoons, especially on the relationship between the water catchment and the lagoons that can provide more knowledge about pressures. Social, economic, and even cultural studies about coastal lagoons are generally not available. These can provide more knowledge about the ES and the impact on human health and human welfare.

\section{CONCLUSION}

The information about North African lagoons is diffuse and heterogeneous, and the terminology is often confusing. North African coastal lagoons are complex, social-ecological environments; thus, an interdisciplinary approach is needed for their analysis and management. The DAPSI(W)R(M) approach used in the research (Elliott et al., 2017) has evolved from the previous applications of DPSIR approach for lagoons analysis (Newton et al., 2014; Dolbeth et al., 2016).

The research mapped the existing North African lagoons, and 11 of 21 coastal lagoons were analyzed. The most common economic sectors and human activities are the extraction of living resources (mostly fishing and aquaculture) followed by agriculture, transport and shipping, land-based industries, coastal infrastructure, and urbanization as secondary major activities in most of the North African lagoons.

The most common pressures in North African lagoons are underwater noise, introduction of synthetic (e.g., pesticides) and non-synthetic compounds (e.g., heavy metals), and input of organic matter (e.g., sewage), as well as nutrient and phosphorus enrichment (e.g., fertilizers).

The least affected of the lagoons is Khenifiss lagoon, an almost pristine system, because it is a protected area and listed as a world heritage site for UNESCO. However, in the remaining North African lagoons, there are many state changes on the environment. These affect lagoon hydrology, salinity, connectivity, erosion and accretion, nutrient and chemical 
contamination, dissolved oxygen, and redox potential to varying degrees. There are also many state changes in the ecology of coastal lagoons both from the ecological components and ecosystem processes, which include intermediate services (supporting and regulating services) and the final ES (provisioning, regulating, and cultural). These changes have led to an impact on human welfare, especially in provisioning services (e.g., revenue from catches and provision of food) and other impacts on human welfare such as health (contaminated seafood).

Lack of knowledge about the value of lagoon ES and the impacts on human welfare hampers the sustainable management of North African lagoons. Some immediate responses as management measures, such as improving UWWTP, could be implemented by North African countries. The complexity of the lagoon systems also calls for the adoption of participatory methods that include all stakeholders in order to manage the multiple issues affecting the social and economic services and ES of these important environments. This can foster a more transdisciplinary approach and improve the implementation of policies aimed at coastal protection and improving ES. An investment in sustainable extraction of resources, bioagriculture, tourism, ecological transport and shipping, and raising awareness could ensure the blue growth of the lagoons in North Africa benefiting both the surrounding population and the ecology.

In summary, DAPSI $(\mathrm{W}) \mathrm{R}(\mathrm{M})$ is an adaptive management framework for social-ecological systems that could provide options for supporting decision makers in North Africa with science-based knowledge to deliver sustainable development to the North African lagoons.

\section{DATA AVAILABILITY STATEMENT}

All datasets generated for this study are included in the article/Supplementary Material.

\section{REFERENCES}

Abdel, S. A. (2015). Trace metals in seawater, sediments and some fish species from Marsa Matrouh beaches in north-western Mediterranean coast. Egypt. Egypt. J. Aquat. Res. 41, 145-154. doi: 10.1016/j.ejar.2015. 02.006

Abdel Razek, F. A., Ismaiel, M., and Ameran, M. A. A. (2016). Occurrence of the blue crab Callinectes sapidus, Rathbun, 1896, and its fisheries biology in Bardawil lagoon, Sinai peninsula, Egypt. Egypt. J. Aquat. Res. 42, 223-229. doi: 10.1016/j.ejar.2016.04.005

Abidli, S., Lahbib, Y., González, P. R., Alonso, J. I. G., Trigui, and El Menif, N. (2016). Butyltin compounds in sediment and biota from the lagoon of Bizerte (northern Tunisia): potential risk for consumers? Hum. Ecol. Risk Assess. 22, 337-349. doi: 10.1080/10807039.2015.1064761

Alves Martins, M. V., Zaaboub, N., Aleya, L., Frontalini, F., Pereira, E., Miranda, P., et al. (2015). Environmental quality assessment of Bizerte Lagoon (Tunisia) using living foraminifera assemblages and a multiproxy approach. PLoS One 10:e137250. doi: 10.1371/journal.pone.013 7250

Ayache, F., Thompson, J. R., Flower, R. J., Boujarra, A., Rouatbi, F., and Makina, H. (2009). Environmental characteristics, landscape history and pressures on three coastal lagoons in the southern Mediterranean region: Merja Zerga (Morocco), Ghar El Melh (Tunisia) and Lake Manzala (Egypt). Hydrobiologia 622, 15-43. doi: 10.1007/s10750-008-9676-6

\section{AUTHOR CONTRIBUTIONS}

All authors helped to shape the research, analysis, and manuscript and provided the critical feedback. All authors discussed the results and contributed to the final version of the manuscript.

\section{FUNDING}

This work has been funded and supported by the Murray Foundation supporting student-research, https://www. murrayfoundation.eu, Grant Agreement No. 25.29012019.

\section{ACKNOWLEDGMENTS}

BE would like to thank Drs. Björn Kjerfve and Martin Le Tissier for their valuable help, knowledge sharing, and support regarding technical aspects of this research, and also he would like to acknowledge the Murray Foundation, Centro de Investigação Marinha e Ambiental, Erasmus Mundus WACOMA programme, Sustainable Blue Growth programme, and BlueMed Initiative. AN acknowledges SCOR, Future Earth Coasts, IMBeR, and Future Earth Ocean KAN. The authors wish to thank the reviewers and the editor for their comments that have helped to improve the manuscript.

\section{SUPPLEMENTARY MATERIAL}

The Supplementary Material for this article can be found online at: https://www.frontiersin.org/articles/10.3389/fenvs. 2020.00037/full\#supplementary-material

Banana, A. A. S., and Mohamed, R. M. S. R. (2016). Mercury pollution for marine environment at Farwa Island. Libya. J. Environ. Heal. Sci. Eng. 14, 1-8. doi: 10.1186/s40201-016-0246-y

Barhoumi, B., Menach, K. L., Clérandeau, C., Ameur, W. B., Budzinski, H., and Driss, M. R. (2014). Assessment of pollution in the Bizerte lagoon (Tunisia) by the combined use of chemical and biochemical markers in mussels, Mytilus galloprovincialis. Mar. Pollut. Bull. 84, 379-390. doi: 10.1016/j.marpolbul.2014. 05.002

Barnard, S., and Elliott, M. (2015). The 10-tenets of adaptive management and sustainability: an holistic framework for understanding and managing the socio-ecological system. Environ. Sci. Policy 51, 181-191. doi: 10.1016/J. ENVSCI.2015.04.008

Béjaoui, B., Solidoro, C., Harzallah, A., Chevalier, C., Chapelle, A., Zaaboub, N., et al. (2017). 3D modeling of phytoplankton seasonal variation and nutrient budget in a southern Mediterranean Lagoon. Mar. Pollut. Bull. 114, 962-976. doi: 10.1016/J.MARPOLBUL.2016.11.001

Benradia, H., Berghiche, H., and Soltani, N. (2016). Measure of environmental stress biomarkers in the shrimp Palaemon adspersus from the Mellah lagoon (Algeria): spatial and temporal variations. Fresenius Environ. Bull. 25, 25632566.

Beryouni, K., Méar, Y., Murat, A., Poizot, E., and Chaibi, M. (2012). Geographical variability of environmental parameters versus GPS precision: toward a better sampling strategy. Mar. Pollut. Bull. 64, 2507-2518. doi: 10.1016/j.marpolbul. 2012.05.015 
Bocci, M., Brigolin, D., Pranovi, F., Najih, M., Nachite, D., and Pastres, R. (2016). An ecosystem approach for understanding status and changes of Nador lagoon (Morocco): application for of food web models and ecosystem indices. Estuar. Coast. Shelf Sci. 171, 133-143. doi: 10.1016/j.ecss.2016.01.004

Chaoui, L., Kara, M. H., Faure, É, and Quignard, J. (2006). L'ichtyofaune de la lagune du Mellah (Algérie Nord-Est): diversité, production et analyse des captures commerciales. Cybium 30, 123-132.

Chouari, W. (2015). Apport de la cartographie au suivi de l'anthropisation des milieux humides littoraux. Méditerranée 125, 75-84. doi: 10.4000/mediterranee. 8015

Conde, D., Solari, S., de Álava, D., Rodríguez-Gallego, L., Verrastro, N., Chreties, C., et al. (2019). Ecological and social basis for the development of a sand barrier breaching model in Laguna de Rocha. Uruguay. Estuar. Coast. Shelf Sci. 219, 300-316. doi: 10.1016/J.ECSS.2019.02.003

Conseil Economique, Social et Environnemental (2014). Projet de loi n81-12 Relative au Littoral. Available online at: http://www.ces.ma/Documents/PDF/ Saisines/S-13-2014-Projet-de-loi-sur-le-littoral/Avis-S-13-2014-VF.pdf

Daghor, L., Hssaïda, T., Chakir, S., Slimani, H., Mouflih, M., Hamoumi, N., et al. (2016). Etude des kystes de dinoflagellés des sédiments de surface du système lagunaire atlantique marocain Oualidia - Sidi Moussa et de la lagune méditerranéenne de Nador. Bull. l'Institut Sci. Rabat, Sect. Sci. la Terre 38, 1-18.

Damsiri, Z., Elkalay, K., and Khalil, K. (2015). Modelling the biogeochemical cycle of the Oualidia lagoon (Atlantic. Morocco). Int. J. Adv. Res. 3, 18-30.

Damsiri, Z., Natij, L., Elkalay, K., Khalil, K., Loudiki, M., Richir, J., et al. (2017). Seasonal characterization of the nutrients state in Oualidia lagoon (Moroccan atlantic coast). J. Mater. Environ. Sci. 8, 67-77.

Derradji, F., Benmeziane, F., Benaabidate, L., Maoui, A., Bousnoubra, H., and Kherici, N. (2015). Heavy metals analysis in the water of Mellah, Oubeira and Tonga Lakes of El kala wetland complex, North east Algeria. Int. J. Innov. Sci. Res. 13, 107-113.

DGPA (2001). "Etude del'amélioration de la qualité de l'eau de la lagune de BouGhrara," in Phase II -partie I: Etude approfondie de la solution retenue. Direction Générale de la Pêche et de l'Aquaculture, 1-18.

Dolbeth, M., Stålnacke, P., Alves, F. L., Sousa, L. P., Gooch, G. D., Khokhlov, V., et al. (2016). An integrated Pan-European perspective on coastal Lagoons management through a mosaic-DPSIR approach. Sci. Rep. 6, 1-12. doi: 10.1038/ srep19400

EEA (1995). Europe's Environment: The Dobris Assessment. Report No 1/1995. Copenhagen: European Environmental Agency, 8.

Egyptian Environmental Affairs Agency (2009). Environmental Protection Law in Egypt. Available online at: http://www.eeaa.gov.eg/en-us/laws/envlaw.aspx

Eid, E. M., and Shaltout, K. H. (2014). Monthly variations of trace elements accumulation and distribution in above- and below-ground biomass of Phragmites australis (Cav.) Trin. ex Steudel in Lake Burullus (Egypt): a biomonitoring application. Ecol. Eng. 73, 17-25. doi: 10.1016/j.ecoleng.2014. 09.006

El Asri, F., Zidane, H., Errhif, A., Tamsouri, M.-N., Maanan, M., Malouli Idrissi, M., et al. (2017a). Polychaete diversity and assemblage structure in the Oualidia Lagoon, Moroccan Atlantic coast. J. Mar. Biol. Assoc. United Kingdom 98, 1337-1346. doi: 10.1017/S0025315417000388

El Asri, F., Zidane, H., Maanan, M., Tamsouri, M., and Errhif, A. (2015). Taxonomic diversity and structure of the molluscan fauna in Oualidia lagoon (Moroccan Atlantic coast). Environ. Monit. Assess. 187, 545. doi: 10.1007/s10661-015$4752-7$

El Asri, O., Ramdani, M., Latrach, L., Haloui, B., Mohamed, R., and Afilal, M. (2017b). Energetic valorization of Nador lagoon algae and proposal to use it as a means of elimination of the eutrophication in this lagoon. Ecol. Eng. 103, 236-243. doi: 10.1016/j.ecoleng.2017.04.016

El Asri, O., Ramdani, M., Latrach, L., Haloui, B., Ramdani, M., and Afilal, M. E. (2017c). Comparison of energy recovery after anaerobic digestion of three Marchica lagoon algae (Caulerpa prolifera, Colpomenia sinuosa, Gracilaria bursa-pastoris). Sustain. Mater. Technol. 11, 47-52. doi: 10.1016/j.susmat.2016. 12.002

El Nahas, A. F., Abdel-Razek, M. A. S., Helmy, N. M., Mahmoud, S., and Ghazy, H. A. (2017). Impaired antioxidant gene expression by pesticide residues and its relation with other cellular biomarkers in Nile Tilapia (Oreochromis niloticus) from Lake Burullus. Ecotoxicol. Environ. Saf. 137, 202-209. doi: 10.1016/j. ecoenv.2016.12.006
El Yaouti, F., El Mandour, A., Khattach, D., and Kaufmann, O. (2008). Modelling groundwater flow and advective contaminant transport in the Bou-Areg unconfined aquifer (NE Morocco). J. Hydro- Environ.ment Res. 2, 192-209. doi: 10.1016/j.jher.2008.08.003

El-Adawy, A., Negm, A. M., Elzeir, M. A., Saavedra, O. C., El-Shinnawy, I. A., and Nadaoka, K. (2013). Modeling the hydrodynamics and salinity of El-Burullus Lake (Nile Delta, Northern Egypt). J. Clean Energy Technol. 1, 157-163. doi: 10.7763/JOCET.2013.V1.37

El-Amier, Y. A., Elnaggar, A. A., and El-Alfy, M. A. (2017). Evaluation and mapping spatial distribution of bottom sediment heavy metal contamination in Burullus Lake. Egypt. Egypt. J. Basic Appl. Sci. 4, 55-66. doi: 10.1016/j.ejbas.2016.09.005

El-Asmar, H. M., Hereher, M. E., and El Kafrawy, S. B. (2013). Surface area change detection of the Burullus Lagoon, North of the Nile Delta, Egypt, using water indices: a remote sensing approach. Egypt. . J. Remote Sens. Sp. Sci. 16, 119-123. doi: 10.1016/j.ejrs.2013.04.004

Elgharsalli, R., Hili, H. A. E. L., Boubaker, H., Boulaares, K., and Ayari, W. (2016). First record of marteiliosis in Mytilus galloprovincialis in Bizerte lagoon. Bull. Inst. Natn. Scien. Tech. Mer Salammbô 43, 125-132.

El-Kassas, H. Y., Nassar, M. Z. A., and Gharib, S. M. (2016). Study of phytoplankton in a natural hypersaline lagoon in a desert area (Bardawil Lagoon in Northern Sinai. Egypt). Rend. Lincei 27, 483-493. doi: 10.1007/s12210-016-0506-x

Elliott, M. (2013). The 10-tenets for integrated, successful and sustainable marine management. Mar. Pollut. Bull. 74, 1-5. doi: 10.1016/j.marpolbul.2013.08.001

Elliott, M., Burdon, D., Atkins, J. P., Borja, A., Cormier, R., de Jonge, V. N., et al. (2017). "And DPSIR begat DAPSI(W)R(M)!" - A unifying framework for marine environmental management. Mar. Pollut. Bull. 118, 27-40. doi: 10.1016/j.marpolbul.2017.03.049

El-Monsef, A., El-Badry, A., and Khalifa, M. M. (2017). The occurrence and distribution of high-arsenic, selenium, tin and antimony in bottom sediments of Burullus lagoon and its effects on human health, Egypt. J. African Earth Sci. 136, 305-311. doi: 10.1016/j.jafrearsci.2017.08.001

El-Zeiny, A., and El-Kafrawy, S. (2017). Assessment of water pollution induced by human activities in Burullus Lake using Landsat 8 operational land imager and GIS. Egypt. J. Remote Sens. Sp. Sci. 20, S49-S56. doi: 10.1016/j.ejrs.2016.10.002

Embarek, R., Amara, R., and Kara, M. H. (2017). Fish assemblage structure in shallow waters of the Mellah lagoon (Algeria): seasonal and spatial distribution patterns and relation to environmental parameters. Acta Ichthyol. Piscat. 47, 133-144. doi: 10.3750/AIEP/02080

Ennesser, Y., Said, V., and Errier, M. (2011). Évaluation des risques en situation actuelle et à l'horizon 2030 pour la ville de Tunis, Rapport final de phase 1 du projet «Adaptation au changement climatique et aux désastres naturels des villes côtières de l'Afrique du Nord», Egis BCEOM/IAU-IDT/BRGM. Banque Mondiale 1, 1-14.

EPA (1994). "A conceptual framework to support the development and use of environmental information," in Environmental Statistics and Information Division. Office of Policy, Planning and Evaluation. EPA 230-R-94-012 (Washington DC: USEPA).

Essghaier, M. F. A., Etayeb, K. S., Bourass, E., and Joel, P. J. (2013). Status and distribution of coastal birds at Farwa Island. Trav. . l'Institut Sci. Rabat,. Série Zool 78-85.

EU (2000). Directive 2000/60/EC of the European Parliament and of the Council establishing a framework for Community action in the field of water policy. Off.icial J.ournal of the Eur.opean Commun.ities 327, 1-73.

Fadili, A., Najib, S., Mehdi, K., Riss, J., Makan, A., Boutayeb, K., et al. (2016). Hydrochemical features and mineralization processes in coastal groundwater of Oualidia. Morocco. J. African Earth Sci. 116, 233-247. doi: 10.1016/j.jafrearsci. 2016.01.014

Food and Agriculture Organization (1982). Organisation de la pêche dans le Lac Mellah L'Unité Aquacole de El-Kala. Available online at: http://www.fao.org/tempref/FI/CDrom/aquaculture/a0845t/volume1/docrep/ field/007/af018f/AF018F09.htm.

Ferreira, J. G., Nobre, A. M., Simas, T. C., Silva, M. C., Newton, A., Bricker, S. B., et al. (2006). A methodology for defining homogeneous water bodies in estuaries - Application to the transitional systems of the EU Water Framework Directive. Estuar. Coast. Shelf Sci. 66, 468-482. doi: 10.1016/j.ecss.2005.09.016

Fertouna-Bellakhal, M., Dhib, A., Béjaoui, B., Turki, S., and Aleya, L. (2014). Driving factors behind the distribution of dinocyst composition and abundance in surface sediments in a western Mediterranean coastal lagoon: report from a 
high resolution mapping study. Mar. Pollut. Bull. 84, 347-362. doi: 10.1016/J. MARPOLBUL.2014.04.041

Finkl, C. W. (2017). Coastal Wetlands: Alteration and Remediation, Coastal Research Library. Cham. Springer International Publishing.

Flower, R. J., Appleby, P. G., Thompson, J. R., Ahmed, M. H., Ramdani, M., Chouba, L., et al. (2009). Sediment distribution and accumulation in lagoons of the Southern Mediterranean Region (the MELMARINA Project) with special reference to environmental change and aquatic ecosystems. Hydrobiologia 622, 85-112. doi: 10.1007/s10750-008-9677-5

Garali, A., Ben, Ouakad, M., and Gueddari, M. (2009). Bilans hydrologiques de la lagune de Bizerte (nord-est de la Tunisie). Rev. des Sci. l'eau. 22, :525. doi: $10.7202 / 038329$ ar

García-Ayllón, S. (2017). Integrated management in coastal lagoons of highly complexity environments: resilience comparative analysis for three casestudies. Ocean Coast. Manag. 143, 16-25. doi: 10.1016/j.ocecoaman.2016.10.007

Gari, S. R., Newton, A., and Icely, J. D. (2015). A review of the application and evolution of the DPSIR framework with an emphasis on coastal social-ecological systems. Ocean Coast. Manag. 103, 63-77. doi: 10.1016/J. OCECOAMAN.2014.11.013

Gharib, S. M., El-Sherif, Z. M., Abdel-Halim, A. M., and Radwan, A. A. (2011). Phytoplankton and environmental variables as a water quality indicator for the beaches at Matrouh, south-eastern Mediterranean Sea, Egypt: an assessment. Oceanologia 53, 819-836. doi: 10.5697/oc.53-3.819

Ghribi, F., Richir, J., Boussafa, D., El Cafsi, M., and Gobert, S. (2016). Trace metals in soft tissue of marine bivalve Noah's ark (Arca noao) from Bizerte lagoon (Northern Tunisia). Rapp. Comm. Int. Mer Médit. 41:241.

Giuliani, S., Piazza, R., El Moumni, B., Polo, F. P., Vecchiato, M., Romano, S., et al. (2015a). Recognizing different impacts of human and natural sources on the spatial distribution and temporal trends of PAHs and PCBs (including PCB-11) in sediments of the Nador lagoon (Morocco). Sci. Total Environ. 526, 346-357. doi: 10.1016/j.scitotenv.2015.04.057

Giuliani, S., Piazza, R., El Moumni, B., Polo, F. P., Vecchiato, M., Romano, S., et al. (2015b). Recognizing different impacts of human and natural sources on the spatial distribution and temporal trends of PAHs and PCBs (including PCB-11) in sediments of the Nador lagoon (Morocco). Sci. Total Environ. 526, 346-357. doi: 10.1016/j.scitotenv.2015.04.057

Gönenç, I. E., and Wolflin, J. P. (2005). Coastal Lagoons Ecosystem Processes and Modeling for Sustainable Use and Development. Boca Raton, FL: CRC Press.

Gooré, B. E., Monette, F., and Gasperi, J. (2015). Analysis of the influence of rainfall variables on urban effluents concentrations and fluxes in wet weather. J. Hydrol. 523, 320-332. doi: 10.1016/J.JHYDROL.2015.01.017

Guerra-García, J. M., and García-Gómez, J. C. (2005). Assessing pollution levels in sediments of a harbour with two opposing entrances. Environmental implications. J. Environ. Manage. 77, 1-11. doi: 10.1016/J.JENVMAN.2005. 01.023

Ha, E., Basu, N., Bose-O'Reilly, S., Dórea, J. G., McSorley, E., Sakamoto, M., et al. (2017). Current progress on understanding the impact of mercury on human health. Environ. Res. 152, 419-433. doi: 10.1016/J.ENVRES.2016.06.042

Haddoud, D. A., and Rawag, A. A. (1995). Marine Protected Areas along Libyan coast. D. A. Haddoud and A. A. Rawag. Tajura: Marine Biology Research Centre, 23-31.

Hammani, J., Brahim, M., and Gueddari, M. (2016). Assessment of the water quality of Bizerte lagoon of Tunisia by use of statistical analyses. Hydrol. Curr. Res. 7, 1-8. doi: 10.4172/2157-7587.1000237

Huffpostmaghreb (2017). Huffpostmaghreb. Available online at: https: //marocainun.wordpress.com/tag/maroc-the-huffington-post/page/327/

Husain, M., Hassan, H. A. E., Khater, M., and Ghoniem, A. (2016). Analysis of Reinforced Concrete D-Regions Using Strut-and-Tie Model. Egypt. Int. J. Eng. Sci. Technol. 20, 25-37.

Journal Officiel de la Republique Algerienne (2002). Loi n 02-02 du 22 Dhou El Kaada 1422 correspondant au 5 février 2002 relative à la protection et à la valorisation $d u$ littoral. Available online at: http://www.enssmal.dz/fr/images/ Relementation_milieux_marin/Loi_littoral_02-02.pdf.

Kamel, N., Burgeot, T., Banni, M., Chalghaf, M., Devin, S., Minier, C., et al. (2014). Effects of increasing temperatures on biomarker responses and accumulation of hazardous substances in rope mussels (Mytilus galloprovincialis) from Bizerte lagoon. Environ. Sci. Pollut. Res. 21, 6108-6123. doi: 10.1007/s11356-0142540-5

Khaled, A., Hessein, A., Abdel-Halim, A. M., and Morsy, F. M. (2014). Distribution of heavy metals in seaweeds collected along Marsa Matrouh beaches, Egyptian
Mediterranean sea. Egypt. J. Aquat. Res. 40, 363-371. doi: 10.1016/j.ejar.2014. 11.007

Khedhri, I., Afli, A., and Aleya, L. (2017a). Structuring factors of the spatio-temporal variability of macrozoobenthos assemblages in a southern Mediterranean lagoon: how useful for bioindication is a multi-biotic indices approach? Mar. Pollut. Bull. 114, 515-527. doi: 10.1016/j.marpolbul.2016.10.023

Khedhri, I., Afli, A., and Aleya, L. (2017b). Structuring factors of the spatio-temporal variability of macrozoobenthos assemblages in a southern Mediterranean lagoon: how useful for bioindication is a multi-biotic indices approach? Mar. Pollut. Bull. 114, 515-527. doi: 10.1016/J.MARPOLBUL.2016. 10.023

Khedhri, I., Tovar-Hernández, M., Bonifácio, P., Ahmed, A., and Aleya, L. (2017c). First report of the invasive species Branchiomma bairdi McIntosh, 1885 (Annelida: Sabellidae) along the Tunisian coast (Mediterranean Sea). BioInvasions Rec. 6, 139-145. doi: 10.3391/bir.2017.6.2.09

Kherifi, W., and Bousnoubra-Kherici, H. (2016). Study of the influence of the physicochemical parameters on microbial abundance in various ambient conditions. Water Resour. 43, 546-558. doi: 10.1134/S0097807816030180

Kim, K.-H., Kabir, E., and Jahan, S. A. (2016). A review on the distribution of $\mathrm{Hg}$ in the environment and its human health impacts. J. Hazard. Mater. 306, 376-385. doi: 10.1016/J.JHAZMAT.2015.11.031

Lahbib, Y., Abidli, S., and Trigui-El Menif, N. (2018). First assessment of the effectiveness of the international convention on the control of harmful antifouling systems on ships in Tunisia using imposex in Hexaplex trunculus as biomarker. Mar. Pollut. Bull. 128, 17-23. doi: 10.1016/J.MARPOLBUL.2018. 01.012

Lillebø, A. I. (2015). Coastal Lagoons in Europe: Integrated Water Resource Strategies. London: IWA Publishing, 14.

Lillebø, A. I., Stålnacke, P., Gooch, G. D., Krysanova, V., and Bielecka, M. (2017). Pan-European management of coastal lagoons: a science-policy-stakeholder interface perspective. Estuar. Coast. ShelfSci. 198, 648-656. doi: 10.1016/J.ECSS. 2016.03.008

Maanan, M., Ruiz-Fernández, A. C., Maanan, M., Fattal, P., Zourarah, B., and Sahabi, M. (2014). A long-term record of land use change impacts on sediments in Oualidia lagoon. Morocco. Int. J. Sediment Res. 29, 1-10. doi: 10.1016/S10016279(14)60017-2

Magni, P., Draredja, B., Melouah, K., and Como, S. (2015). Patterns of seasonal variation in lagoonal macrozoobenthic assemblages (Mellah lagoon. Algeria). Mar. Environ. Res. 109, 168-176. doi: 10.1016/j.marenvres.2015.07.005

Mahmoud Khamis, E., and El-Sayed El-Sayed, M. (2015). Feeding habits of the copper shark, Carcharhinus brachyurus (Günther, 1870) from Ain El-Ghazala Lagoon, Eastern Libya during the Period from February till June 2013. J. Life Sci. 9, 347-355. doi: 10.17265/1934-7391/2015.08.001

Maslow, A. H. (1943). A theory of human motivation. Psychol. Rev. 50, 370-396. doi: $10.1037 / \mathrm{h} 0054346$

Mebarki, R., El, M., Khebbeb, H., and Soltani, N. (2015). Biomonitoring of El mellah lagoon (Northeast, Algeria): seasonal variation of biomarkers in Cerastoderma glaucum (Mollusc, Bivalvia). J. Entomol. Zool. Stud. JEZS 3, 408-413.

Melouah, K. (2013). Étude de la Faune Malacologique de la Lagune Mellah avec un intérêt Particulier pour le bivalve: Cerastoderma Glaucum. PhD Thesis. Université Badji Mokhtar Algérie.

Mulazzani, L., Zanasi, C., Errico, A., Pugliese, P., Zuccaro, M., Zerrouki, R., et al. (2017). The comparative analysis of Mediterranean coastal communities: six case studies. New medit Mediterr. . J. Econ. Agric. Environ. Rev. Méd. Econ. Agric. Environ. 16, 27-37.

Nadira, S. (2008). Evolution des Peuplements Phytoplanctoniques au Niveau du lac Oubéira Et la lagune El Mellah. PhD Thesis, Annaba: University of Annaba, Annaba. PhD Thesis.

Nadji, S., Amrani, A., Mebarki, R., and Khebbeb, M. E. (2010). Acetylcholinesterase and catalase activities in several tissues of a bivalve mollusc (Ruditapes decussatus) fished from Mellah lagoon (North East of Algeria) after malathion exposure. Ann. Biol. Res. 1, 138-144.

Najih, M., Berday, N., Lamrini, A., Nachite, D., and Zahri, Y. (2015). Situation de la pêche aux petits métiers après l'ouverture du nouveau chenal dans la lagune de Nador. Rev. Marocaine des Sci. Agron. Vét.érinaires 3, $19-30$.

Nassar, K., Mahmod, W. E., Masria, A., Fath, H., and Nadaoka, K. (2018). Numerical simulation of shoreline responses in the vicinity of the western 
artificial inlet of the Bardawil Lagoon. Sinai Peninsula, Egypt. Appl. Ocean Res. 74, 87-101. doi: 10.1016/j.apor.2018.02.015

Nassar, M. Z. A., and Gharib, S. M. (2014). Spatial and temporal patterns of phytoplankton composition in Burullus lagoon, southern Mediterranean coast, Egypt. Egypt. J. Aquat. Res. 40, 133-142. doi: 10.1016/j.ejar.2014.06.004

Newton, A., Brito, A. C., Icely, J. D., Derolez, V., Clara, I., Angus, S., et al. (2018). Assessing, quantifying and valuing the ecosystem services of coastal lagoons. J. Nat. Conserv 44, 50-65. doi: 10.1016/J.JNC.2018.02.009

Newton, A., and Elliott, M. (2016). A typology of stakeholders and guidelines for engagement in transdisciplinary, participatory processes. Front. Mar. Sci. 3:230. doi: $10.3389 /$ fmars.2016.00230

Newton, A., Icely, J., Cristina, S., Brito, A., Cardoso, A. C., Colijn, F., et al. (2014). An overview of ecological status, vulnerability and future perspectives of European large shallow, semi-enclosed coastal systems, lagoons and transitional waters. Estuar. Coast. Shelf Sci. 140, 95-122. doi: 10.1016/j.ecss.2013.05.023

Oczkowski, A., Nixon, S., Granger, S., El-Sayed, A. F. M., Altabet, M., and McKinney, R. (2008). A preliminary survey of the nitrogen and carbon isotope characteristics of fish from the lagoons of Egypt's Nile delta. Estuaries and Coasts 31, 1130-1142. doi: 10.1007/s12237-008-9102-3

OECD (1994). Environmental Indicators- OECD Core Set. Organisation for Economic Co-operation and Development. Paris: OECD, 37.

Orabi, O. H., El-Badry, A. A., and Badr-ElDin, A. M. (2017). Benthic foraminifera for heavy metal pollution monitoring: a case study from Burullus Lagoon of Egypt. Mar. Pollut. Bull. 121, 411-417. doi: 10.1016/j.marpolbul.2017.06.015

Patrício, J., Elliott, M., Mazik, K., Papadopoulou, K.-N., and Smith, C. J. (2016). DPSIR-Two decades of trying to develop a unifying framework for marine environmental management? Front. Mar. Sci. 3:177. doi: 10.3389/fmars.2016. 00177

Piazza, R., Bellucci, L. G., Giuliani, S., Romano, S., Frignani, M., Pizzini, S., et al. (2016). Can PBDE natural formation and degradation processes interfere with the identification of anthropogenic trends and sources? Evidences from sediments of the Nador Lagoon (Morocco). Mar. Pollut. Bull. 108, 15-23. doi: 10.1016/j.marpolbul.2016.05.007

Raji, O., Dezileau, L., Tessier, B., Niazi, S., Snoussi, M., Von Grafenstein, U., et al. (2018). Climate and tectonic-driven sedimentary infill of a lagoon as revealed by high resolution seismic and core data (the Nador lagoon. NE Morocco). Mar. Geol. 398, 99-111. doi: 10.1016/J.MARGEO.2018.01.010

Raji, O., Niazi, S., Snoussi, M., Dezileau, L., and Khouakhi, A. (2013). Vulnerability assessment of a lagoon to sea level rise and storm events: Nador lagoon (NE Morocco). J. Coast. Res. 65, 802-807. doi: 10.2112/SI65-136.1

Ramdani, M., Elkhiati, N., and Flower, R. J. (2009a). Lakes of Africa: North of Sahara, in: Encyclopedia of Inland Waters. Amsterdam: Elsevier, 544-554. doi: 10.1016/B978-012370626-3.00035-1

Ramdani, M., Elkhiati, N., Flower, R. J., Thompson, J. R., Chouba, L., Kraiem, M. M., et al. (2009b). Environmental influences on the qualitative and quantitative composition of phytoplankton and zooplankton in North African coastal lagoons. Hydrobiologia 622, 113-131. doi: 10.1007/s10750-008-9678-4

Ramdani, M., Flower, R. J., Elkhiati, N., Kraïem, M. M., Fathi, A. A., Birks, H. H., et al. (2001). North African wetland lakes: characterization of nine sites included in the Cassarina Project. Aquat. Ecol 35, 281-302. doi: 10.1023/A: 1011957324901

Rapport, D., and Friend, A. (1979). "Towards a comprehensive framework for environmental statistics: a stress-response approach," in Statistics Canada Catalogue (Ottawa: Minister of Supply and Services Canada), 11-510.

Re, V., and Sacchi, E. (2017). Tackling the salinity-pollution nexus in coastal aquifers from arid regions using nitrate and boron isotopes. Environ. Sci. Pollut. Res. 24, 13247-13261. doi: 10.1007/s11356-017-8384-z

Rocheta, V. L. S., Isidoro, J. M. G. P., and de Lima, J. L. M. P. (2017). Infiltration of Portuguese cobblestone pavements-An exploratory assessment using a doublering infiltrometer. Urban Water J. 14, 291-297. doi: 10.1080/1573062X.2015. 1111914

Ruiz, F., Abad, M., Olías, M., Galán, E., González, I., Aguilá, E., et al. (2006). The present environmental scenario of the Nador Lagoon (Morocco). Environ. Res. 102, 215-229. doi: 10.1016/j.envres.2006.03.001

Sayoud, M. S., Salhi, H., Chalabi, B., Allali, A., Dakki, M., Qninba, A., et al. (2017). The first coordinated trans-North African mid-winter waterbird census: the contribution of the International Waterbird Census to the conservation of waterbirds and wetlands at a biogeographical level. Biol. Conserv. 206, 11-20. doi: $10.1016 /$ j.biocon.2016.12.005
Secrétariat Général du Gouvernement Marocain (2017). Projet de loi Relative à la Préservation des Écosystèmes Halieutiques et à Laprotection du Milieu Marin contre la Pollution. Avaliable at: http://www.sgg.gov.ma/portals/0/AvantProjet/ 63/Avp_loi_42-13_Fr.pdf

Smith, C. J., Papadopoulou, K.-N., Barnard, S., Mazik, K., Elliott, M., Patrício, J., et al. (2016). Managing the marine environment, conceptual models and assessment considerations for the European marine strategy framework directive. Front. Mar. Sci. 3:144. doi: 10.3389/fmars.2016.00144

Telailia, S., Boutabia, L., Khemis, M. D. E.-H., Elafri, A., and Djebbari, N. (2017). Multi-annual and seasonal patterns of waterbird assemblages in a Mediterranean coastal lagoon (El Mellah lagoon) of Northeastern Algeria. Ekológia (Bratislava) 36, 146-157. doi: 10.1515/eko-2017-0013

Temraz, T. A., Zedan, H., Fouda, M., Saber, M., Salama, W., and Harhash, K. A. (2016). Egyptian biodiversity strategy and action plan (2015-2030). Minist. Envirnoment 1-83.

Thompson, J. R., and Flower, R. J. (2009). Environmental science and management of coastal lagoons in the southern Mediterranean region: key issues revealed by the MELMARINA project. . Hydrobiologia

Thompson, J. R., Flower, R. J., Ramdani, M., Ayache, F., Ahmed, M. H., Rasmussen, E. K., et al. (2009). Hydrological characteristics of three North African coastal lagoons: Insights from the MELMARINA project. Hydrobiologia 622, 45-84. doi: 10.1007/s10750-008-9680-x

Thornton, S. E., Pilkey, O. H., Doyle, L. J., and Whawling, P. J. (1980). Holocene evolution of a coastal lagoon, Lake of Tunis, Tunisia. Sedimentology 27, 79-91. doi: 10.1111/j.1365-3091.1980.tb01159.x

Tlig-Zouari, S., and Maamouri-Mokhtar, F. (2008). Macrozoobenthic species composition and distribution in the Northern lagoon of Tunis. Transitional Waters Bull. 2, 1-15. doi: 10.1285/i18252273v2n2p1

Trabelsi, E. L. B., Armi, Z., Trabelsi-Annabi, N., Shili, A., Maiz, N., and Ben. (2013). Water quality variables as indicators in the restoration impact assessment of the north lagoon of Tunis, South Mediterranean. J. Sea Res. 79, 12-19. doi: 10.1016/j.seares.2013.01.003

Trigui, N., Menif, E., Kara, H., and Mahé, G. (2012). Final Project Report for 2011 START Grants for Global Change Research in Africa Sensitivity of Coastal Lagoon Ecosystems to Climate and Related Global Changes: Developing a North African Lagoons Network.

Turki, S., Dhib, A., Fertouna-Bellakhal, M., Frossard, V., Balti, N., Kharrat, R., et al. (2014). Harmful algal blooms (HABs) associated with phycotoxins in shellfish: what can be learned from five years of monitoring in Bizerte Lagoon (Southern Mediterranean Sea)? Ecol. Eng. 67, 39-47. doi: 10.1016/J.ECOLENG.2014. 03.028

UN (2015). Transforming our world: the 2030 agenda for sustainable development. In: Resolution Adopted by the General Assembly on 25 September 2015. Seventieth Session, Agenda Items 15 and 116. A/RES/70/1. Available online at: https://daccess-ods.un.org/access.nsf/GetFile?OpenAgent\&DS=A/RES/70/ $1 \&$ Lang=E\&Type $=$ DOC.

UNEP (1994). World Environment Outlook: Brainstorming Session. ENEP/EAMR. 94-5. Environment Assessment Programe Nairobi. United Nations Environment Programme.

Vandenbroeck, J., and Rafik, B. C. (2001). Restoration and development project of south lake of Tunis and its shores. Terra Aqua 11-20.

Wolanski, E., and Elliott, M. (2015). Estuarine ecohydrology: an introduction. doi: 10.1016/B978-008045405-4.00044-6

Yamna, T., Algouti, Ahmed, Algouti, Abdellah, Kheir Addin, A., et al. (2014). Apport de la télédétection à l'étude de la dynamique sédimentaire au sein de la lagune Oualidia (Maroc). Eur. Sci. J. 10, 175-185.

Conflict of Interest: The authors declare that the research was conducted in the absence of any commercial or financial relationships that could be construed as a potential conflict of interest.

Copyright (๔) 2020 El Mahrad, Abalansa, Newton, Icely, Snoussi and Kacimi. This is an open-access article distributed under the terms of the Creative Commons Attribution License (CC BY). The use, distribution or reproduction in other forums is permitted, provided the original author(s) and the copyright owner(s) are credited and that the original publication in this journal is cited, in accordance with accepted academic practice. No use, distribution or reproduction is permitted which does not comply with these terms. 